Int. J. Dev. Biol. 54: 531-543 (2010)

doi: $10.1387 /$ ijdb.082767hg

\title{
Naturally acquired microchimerism
}

\author{
HILARY S. GAMMILL* ${ }^{* 1,2}$ and J. LEE NELSON 1,3 \\ ${ }^{1}$ Department of Clinical Research, Fred Hutchinson Cancer Research Center, \\ ${ }^{2}$ Department of Obstetrics and Gynecology, Maternal-Fetal Medicine, University of Washington and \\ ${ }^{3}$ Department of Medicine, Rheumatology, University of Washington, Seattle, Washington, USA
}

\begin{abstract}
Bi-directional transplacental trafficking occurs routinely during the course of normal pregnancy, from fetus to mother and from mother to fetus. In addition to a variety of cell-free substances, it is now well recognized that some cells are also exchanged. Microchimerism refers to a small number of cells (or DNA) harbored by one individual that originated in a genetically different individual. While microchimerism can be the result of iatrogenic interventions such as transplantation or transfusion, by far the most common source is naturally acquired microchimerism from maternal-fetal trafficking during pregnancy. Microchimerism is a subject of much current interest for a number of reasons. During pregnancy, fetal microchimerism can be sought from the mother's blood for the purpose of prenatal diagnosis. Moreover, studies of fetal microchimerism during pregnancy may offer insight into complications of pregnancy, such as preeclampsia, as well as insights into the pathogenesis of autoimmune diseases such as rheumatoid arthritis which usually ameliorates during pregnancy. Furthermore, it is now known that microchimerism persists decades later, both fetal microchimerism in women who have been pregnant and maternal microchimerism in her progeny. Investigation of the long-term consequences of fetal and maternal microchimerism is another exciting frontier of active study, with initial results pointing both to adverse and beneficial effects. This review will provide an overview of microchimerism during pregnancy and of current knowledge regarding long-term effects of naturally acquired fetal and maternal microchimerism.
\end{abstract}

KEY WORDS: microchimerism, pregnancy, fetal-maternal trafficking, autoimmune disease

\section{Historical perspectives and overview}

Microchimerism (Mc) is the presence of a small amount of foreign cells or DNA within the tissues or circulation of an individual. Mc primarily naturally derives from the exchange of material between a mother and her fetus during pregnancy, and it may persist long-term in both. We are just beginning to understand the implications of these "inhabitants" which may be beneficial or detrimental for the health of the "host".

An earlier obstetric view of the placenta assumed perfect separation of the semi-allogeneic fetus from the mother. As described in a 1907 edition of Williams's textbook of obstetrics: "The foetal blood in the vessels of the chorionic villi at no time gains access to the maternal blood in the intervillous spaces..."(Williams 1907). However, as early as 1893, Georg Schmorl observed fetal material in tissues of women who had died from eclampsia (Schmorl 1893; Lapaire et al. 2007). During the 1960s and 1970s, investigators demonstrated the presence of fetal leukocytes in maternal circulation (Walknowska et al. 1969; Schroder et al. 1972; Schroder et al. 1974). Such fetal cells were initially detected as early as 15 weeks of gestation (Herzenberg et al. 1979).

While the mother acquires fetal cells during pregnancy, the

Abbreviations used in this paper: EGFP, enhanced green fluorescent protein; FISH, fluorescence in situ hybridization; FMc, fetal microchimerism; GCSF, granulocyte-colony stimulating factor; GVHD, graft versus host disease; HELLP Syndrome, hemolysis, elevated liver enzymes, and low platelets; HLA, human leukocyte antigen; HP, hypersensitivity pneumonitis; Mc, microchimerism; MHC, major histocompatibility complex; MMc, maternal microchimerism; NIMA, non-inherited maternal antigen; NIPA, noninherited paternal antigen; NK cell, natural killer cell; PBC, primary biliary cirrhosis; PBMC, peripheral blood mononuclear cells; PCR, polymerase chain reaction; Q-PCR, quantitative polymerase chain reaction; RA, rheumatoid arthritis; SCID, severe combined immunodeficiency; SSc, systemic sclerosis; VEGF-A, vascular endothelial growth factor-A.

\footnotetext{
*Address correspondence to: Hilary S. Gammill. Immunogenetics, D2-100, Fred Hutchinson Cancer Research Center, 1100 Fairview Ave N, P.O. Box 19024, Seattle, WA 98109, USA. Fax: +1-206-667-5225. e-mail: hgammill@u.washington.edu
}

ISSN: Online 1696-3547, Print 0214-6282 
fetus acquires maternal cells. Early evidence of maternal cell transfer to the fetus came from the demonstration of transplacental metastases of maternal melanoma (Reynolds 1955; Freedman et al. 1960).

Exchange from mother to fetus may have different immunologic consequences than fetus to mother transfer, as the acquisition of maternal cells by the fetus occurs in a nascent immune system. In 1953, Billingham and Medawar conducted experiments in animal models demonstrating the fundamental concept of active acquisition of tolerance in the fetus. At this early date, they began to speculate as to the relevance of their results to physiologic processes: "Actively acquired tolerance may not be a wholly artificial phenomenon. We are inquiring into the possibility that it may occur naturally by the accidental incorporation of maternal cells into a foetus during normal development (Billingham et al. 1953).

Human correlation of this phenomenon derives from observations in transplantation. In 1988, Claas et al., investigated a group of renal transplant patients who had previously received large numbers of transfusions. In an attempt to find permissible matched grafts for these individuals, the investigators found that there was preferential nonresponsiveness to their non-inherited maternal antigen (NIMA), as compared with the non-inherited paternal antigen (NIPA). They suggested this tolerance may have been induced by fetal exposure to maternal cells, resulting in "true tolerance maintained by chimerism" (Claas et al. 1988).

More recently long-term persistence of fetal microchimerism (FMc) in the mother has been recognized. A 1996 study of women who had given birth to sons found male DNA in 6 of 8 women including women who had given birth to their sons decades previously (Bianchi et al. 1996). Testing for male DNA (or male cells) in a woman with prior pregnancies is the most common approach used to identify presumptive FMc. This approach is taken not because of any biological difference in FMc from a son than from a daughter, but rather for practical reasons because a single test can be employed and many women tested. Persistence of maternal microchimerism (MMc) had been recognized by the 1980s, but studies were limited to children with immune deficiencies (Pollack et al. 1982). Long-term persistence of MMc in individuals without immune deficiency including in healthy adults was described in a 1999 report (Maloney etal. 1999). Thus, bi-directional trafficking during pregnancy routinely results in the acquisition of both FMc in the mother and MMc in her offspring. (See Fig. 1.)

This review will summarize current understanding of naturally acquired Mc, focusing on fetal and maternal sources. The frequency with which Mc occurs, the form in which it originates, and relevant disease associations will be discussed. We will explore unanswered questions about Mc that, when better understood, will enable us to appreciate its functionality and, ultimately, to harness its therapeutic potential.

\section{Fetal microchimerism}

\section{Feasibility of noninvasive prenatal diagnosis}

Many early investigations of fetomaternal cell trafficking primarily sought to develop methods whereby noninvasive prenatal diagnosis of aneuploidy and other genetic disorders could be accomplished. Karyotypic analysis and quinacrine staining for $Y$

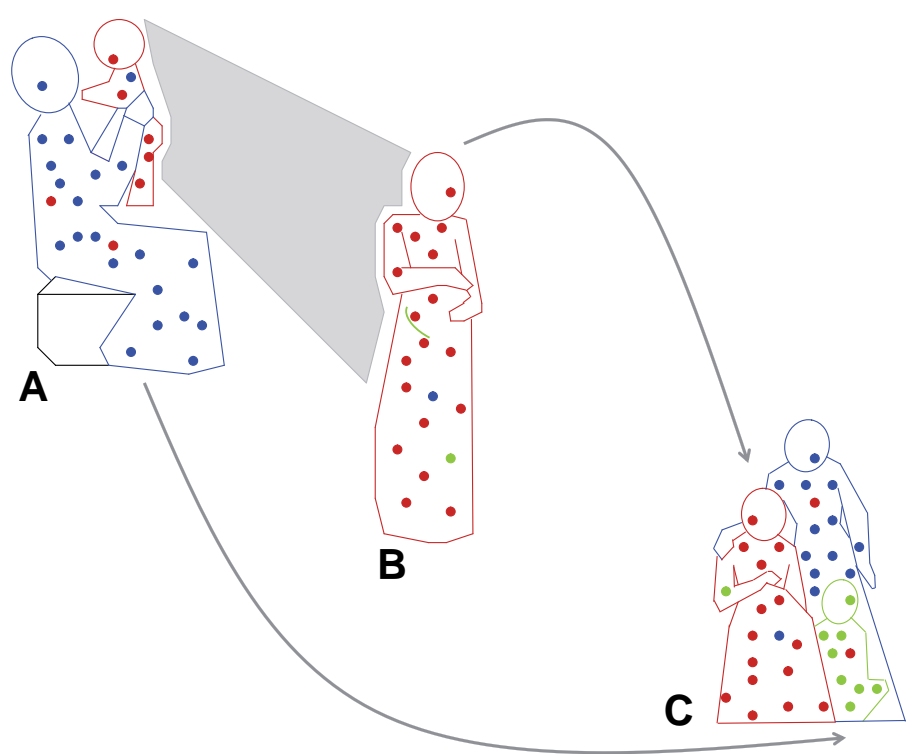

Fig. 1. Microchimerism (Mc) in three generations. (A) Proband as infant (red) exchanges Mc with her mother (blue), resulting in maternal $M c$ in the infant and fetal Mc in the mother. (B) As an adult, proband (red), still harboring maternal Mc, experiences pregnancy herself (green) and acquires new source of fetal Mc. (C) Later, proband (red), child (green), and proband's mother (b/ue), all with persistent Mc from maternal and/ or fetal sources.

chromosome detection in lymphocytes in maternal circulation was used in this regard by several groups decades ago (Walknowska et al. 1969; Schroder et al. 1972; Schroder et al. 1974).

Various techniques for fetal cell enrichment have been developed (Herzenberg et al. 1979; Bianchi et al. 1990; Cox et al. 2003). As molecular techniques have advanced, realization of the goal of achieving noninvasive prenatal diagnosis has become more likely. In addition, consideration of plasma fetal DNA concentration as an adjunct to current screening tests for aneuploidy has also been suggested, as the amount of fetal DNA in maternal circulation is higher in pregnancies with aneuploid fetuses than with euploid fetuses (Bianchi et al. 1997; Lo et al. 1999; Lo et al. 2007).

\section{FMc kinetics in normal pregnancy}

Prenatal diagnostic investigations have resulted in a body of literature describing the kinetics of fetal DNA detection in maternal plasma. The primary markers utilized to evaluate fetal material in maternal blood and tissues are based on Y-chromosome detection. Polymerase chain reaction (PCR) and in situhybridization analyses (example in Fig. 2) have been used most commonly, with increasing utilization of quantitative PCR approaches (QPCR). Employing these techniques, it has been shown that FMc, both in cellular form and in free DNA, is quite common, with 70$80 \%$ of maternal plasma or serum specimens positive for male DNA, and at least $17 \%$ positivity in cellular material (Lo et al. 1997). Quantitative studies indicate that male DNA accounts for $3-6 \%$ of total DNA in maternal plasma (Lo et al. 1998). FMc is detectable during pregnancy in maternal blood as early as 4-5 weeks gestational age (Thomas et al. 1994). The concentration of 
FMc seems to increase steadily after 24 weeks gestation, peaking at parturition and declining postpartum (Ariga et al. 2001).

Postpartum clearance of free FMc has been investigated in serial sampling in normal pregnancies; the data indicates clearance is rapid, with a mean half-life of approximately 16 minutes and $100 \%$ clearance by one day after delivery'(Lo et al. 1999). These findings have been corroborated in other studies (Kolialexi et al. 2004), although one group found positive results in approximately $20 \%$ of samples in a cross-sectional study of women with a remote history of delivery of a son (Invernizzi et al. 2002). Technical differences in the processing of maternal samples may account for this discrepancy, as studies have shown that different plasma separation techniques yield different data (Chiu et al. 2001). A variable that could influence results and is influenced by processing techniques is the presence of apoptotic fetal cellular material in maternal plasma (van Wijk et al. 2000). Such variation, as well as differences in "free fetal DNA" in plasma compared with serum (Lee et al. 2001), are important considerations in the field of prenatal diagnosis and also potentially could affect diverse areas, such as forensics (Klintschar et al. 2006).

\section{FMc alterations in abnormal pregnancy}

FMc has been investigated in a number of adverse pregnancy outcomes, particularly those likely to stem from abnormal placentation. As noted previously, the first documentation of transfer of fetal material into the maternal system is attributed to Georg Schmorl in an 1893 study of eclampsia (seizures in pregnancy). Detailed analysis was conducted of autopsy tissue from 17 women who died from eclampsia. He identified multinucleated cells in maternal lung and other tissues and systematically assessed the likelihood that these were of placental origin. Remarkably, he also described fetomaternal trafficking in normal pregnancies but estimated significant quantitative differences in pregnancies complicated by eclampsia (Schmorl 1893; Lapaire et al. 2007).

More recently the early findings of Schmorl have been confirmed in studies employing molecular techniques that have identified increased numbers of fetal erythroblasts and increased amounts of free fetal DNA in maternal circulation in preeclampsia compared with normal pregnancy (Holzgreve et al. 1998; Lo et al. 1999; Zhong et al. 2001). Similar findings, even more marked, have been reported in a severe variant of preeclampsia called HELLP syndrome (hemolysis, elevated liver enzymes, and low platelets) (Swinkels et al. 2002). This may be related to increased fetomaternal transfer or due to diminished maternal clearance capacity (Lau et al. 2002).

Increased fetomaternal trafficking has been described in other pregnancy disorders which share underlying placental abnormalities, including fetal growth restriction and preterm labor (Leung et al. 1998; Al-Mufti et al. 2000). In addition, iatrogenic obstetric interventions may increase the maternal receipt of fetal material. External cephalic version has been shown to result in a substantial increase in free fetal DNA in maternal circulation (Lau et al. 2000). Termination of pregnancy results in a substantial release of fetal material into maternal circulation (Bianchi et al. 2001). FMc can also occur after spontaneous abortion. It has been speculated that greater capacity for fetal cell differentiation in early gestation confers a higher probability of FMc engraftment (Kiarash Khosrotehrani 2003; McGrath 2004). Long-term persis- tent FMc has been described in women with no history of childbirth but with a history of spontaneous abortion as well as women who have only a history of elective termination; of additional note, in that study the highest prevalence and highest levels of FMc were observed in women who had a past history of elective abortion. (Yan et al. 2005).

\section{FMc and amelioration of rheumatoid arthritis during preg- nancy}

Rheumatoid arthritis (RA) is a relatively common autoimmune disorder for which the hallmark feature is symmetrical inflammatory arthritis that causes pain, stiffness, swelling, and limited function of multiple joints. More than 70 years ago, Hench reported the observation that pregnancy induces amelioration of RA for most women (Hench 1938). Arthritis recurs after delivery usually within 3 months (Ostensen et al. 2004). Plasma cortisol, which rises during pregnancy to peak at term, was initially thought to be important in the pregnancy-induced amelioration of RA (Hench 1938), but arthritis improvement was not explainable by changes in cortisol in subsequent studies, or by changes in sex hormone levels (Ostensen et al. 2004). The hypothesis was later proposed that FMc of the mother might be responsible. In the early 1990's indirect evidence was reported to support this hypothesis. Fetal-maternal disparity for HLA (human leukocyte antigen) class II molecules was found to correlate with pregnancy-induced improvement of arthritis (Nelson et al. 1993). When the fetus was more disparate from the mother for HLA class II molecules, arthritis was more likely to improve, and when similar, arthritis remained active or even worsened.

After the technology became available to identify and quantify FMc a subsequent study was done in which FMc was measured in blood samples from women with RA over the course of pregnancy and postpartum. The study found a significant inverse correlation of FMc with arthritis activity i.e. higher levels of FMc were found when arthritis was quiescent and lower levels when it was active (Yan et al. 2006). A step by step mechanistic hypoth-

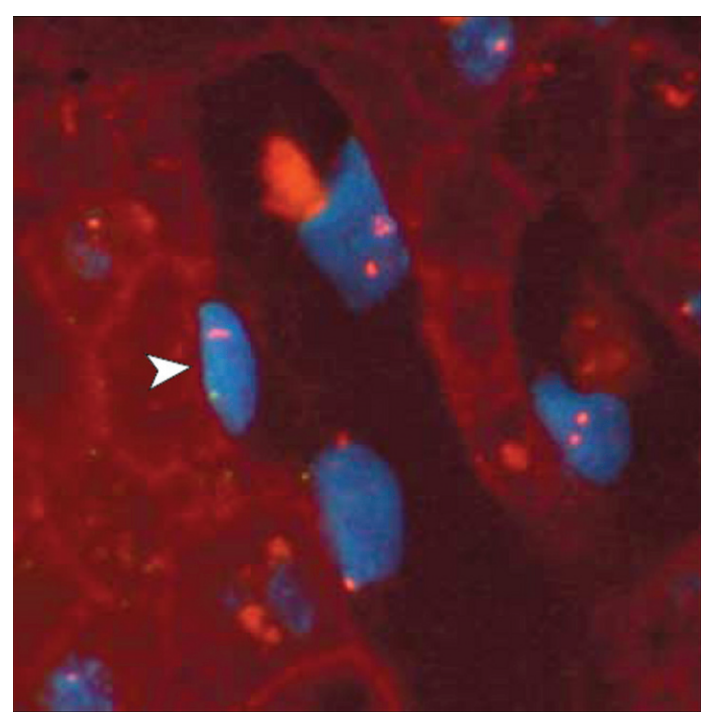

Fig. 2. Male cell in female liver by fluorescence in situ hybridization. Reproduced with permission from JAMA, 2004; 291:1128, Copyright (C) 2004 American Medical Association. 
esis for how FMc might induce arthritis remission was recently described (Adams et al. 2007). In this paper "The Changing Self Hypothesis," events in placental biology and immunologic changes that occur as part of normal pregnancy due to the need for maternal tolerance to disparate fetal HLA antigens are proposed to secondarily result in improvement of the mother's autoimmune arthritis symptoms. Most autoimmune diseases do not improve during pregnancy. However, similar mechanisms could play a role in the improvement that is observed in two other autoimmune diseases, multiple sclerosis and Graves' thyroiditis.

\section{Long-term persistent FMc and its functional capacity}

While earlier studies suggested FMc can sometimes be found in women who were previously pregnant, that FMc commonly persists long-term including in healthy women has only recently been appreciated. In a study that isolated progenitor cells (CD34+CD38+) from 8 women who had previously given birth to sons male DNA (presumed FMc) was found in 6 including one woman for whom the son was born 27 years earlier (Bianchi et al. 1996). FMc has been described within a wide variety of different cell types, presumptive evidence of engraftment of women with fetal stem cells. FMc has also been demonstrated in CD34enriched products (Adams et al. 2003; Guetta et al. 2003; Mikhail et al. 2008). In apheresis products from female hematopoietic cell transplantation donors, $34 \%$ of growth factor mobilized apheresis products were positive for male DNA (presumed FMc) and within CD34-enriched products $48 \%$ were positive (Adams et al. 2003). CD34+ cells that are adherent in culture represent a population of cells with particularly broad differentiation potential and in another study, up to $11 \%$ of these cells were male in female test subjects (Mikhail et al. 2008). In another study of bone marrow-derived mesenchymal stem cells, male DNA was uniformly identified in women who had sons and was not found in women with daughters or no pregnancies (O'Donoghue et al. 2004). Whether mesenchymal cells represent an entirely different population or a transdifferentiated form of an hematopoietic stem cell remains unresolved (Rossi 2004). FMc has also been identified within T cells, B cells, monocyte/macrophages and natural killer cells in healthy women and in women with autoimmune disease, as will be discussed in more detail below (Evans et al. 1999).

FMc has been investigated within multiple different types of tissues obtained from biopsies or autopsies. Conducting studies of women who had sons, and assessing FMc by testing either for male DNA or by fluorescence in situhybridization for male cells, FMc has been found in liver, thyroid, cervix, gallbladder, intestine, spleen, lymph nodes, heart, and kidneys (Khosrotehrani et al. 2004; Stevens et al. 2004; Bayes-Genis et al. 2005; Koopmans et al. 2005; Koopmans et al. 2008). Some studies have also evaluated the cellular phenotype of FMc in tissues. Interestingly, these studies have found that some FMc in tissues expresses cell surface markers indicating the cells are tissue specific including for example hepatocytes and cardiomyocytes (Khosrotehrani et al. 2004; Stevens et al. 2004; Bayes-Genis et al. 2005).

Similarity to human fetal-maternal trafficking has been described in mice and in Rhesus monkeys (Jimenez et al. 2003; Jimenez et al. 2005; Khosrotehrani et al. 2005). Observations in animal models have provided additional insights. In mice, fetal CD4+CD8+ cells were found in the maternal thymus presumably as a precursor to the development of functional $\mathrm{T}$ cells
(Khosrotehrani et al. 2008). In other murine studies, fetal cells were found in the maternal brain and appeared to adopt tissuespecific phenotypes (Tan et al. 2005).

\section{Long-term persistent FMc and its relationship with the host}

The long-term consequences of fetal inhabitants of the maternal system are not yet known. The potential range of effects is pleiotropic with both detrimental and beneficial consequences proposed. There are numerous variables that potentially could influence the impact of FMc on a woman. In addition to the source of origin of the FMc (e.g. from a birth vs. a spontaneous abortion) and the amount of time elapsed since the acquisition of FMc, it is likely that genetic factors are important. HLA genes are wellrecognized as key determinants of immune responses, the donorrecipient HLA-relationship is a critical determinant of transplantation success and specific HLA class II genes are associated with a variety of autoimmune diseases. Thus considering the foregoing observations from other areas of research it seems likely that HLA genes and the HLA-contextual relationship of FMc to a woman impact the maternal response to a fetal inoculum, the potential for those fetal cells to engraft and persist, and the ultimate consequences of such interactions on maternal longterm health.

In studies of systemic sclerosis (SSc), women with SSc and their children born prior to disease onset were HLA-genotyped and compared to mothers who were healthy and their children; the women with SSc significantly more often than controls had given birth to a child who had excess similarity to the mother for HLADRB1, an HLA class II gene (Nelson et al. 1998). In another study the HLA class II genotype of the son (DQA1*0501) was significantly associated with persistent FMc within maternal T (CD3+) cells. While the association of DQA $1{ }^{*} 0501$ with Mc was not observed in another study, methodological differences may account for this discrepancy (Artlett et al. 2003). Among women with SSc a number of studies have found an increased frequency of DRB1*11 and DRB1*03, and among men DRB1*03 and $\mathrm{DQA} 1{ }^{*} 0501$ (Caucasians). Thus the HLA-relationship of FMc to a woman, the specific HLA alleles of the FMc and the specific HLA alleles of an individual all have the capacity to contribute to risk of an autoimmune disease such as SSc. Increased levels of FMc have also been described in the peripheral blood of women with SSc compared to controls (Nelson et al. 1998).

The influence of intergenerational histocompatibility on the development of cellular and tissue FMc is emphasized by studies in a mouse model designed to investigate the maternal immune response to acquired fetal cells. In these studies Bonney and colleagues demonstrated that mice mated syngeneically were significantly more likely to develop persistent FMc than those mated allogeneically (Bonney et al. 1997).

\section{FMc, malevolence or beneficence? \\ Malevolence: FMc implicated in systemic sclerosis}

SSc, like many autoimmune diseases, is increased among women, especially in post-reproductive years. SSc has clinical similarities with a known condition of chimerism, chronic graftversus-host disease (GVHD) that occurs as a complication of hematopoietic cell transplantation. The HLA-relationship of a transplant recipient and the donor is recognized as the key determinant of GVHD. Considering these observations together 
along with the long-term persistence of Mc from fetal-maternal cell transfer, led to the hypothesis that Mc and the HLA-relationship of the Mc to the host plays a role in autoimmune diseases such as SSc (Nelson 1996). A question proposed in this hypothesis is whether some autoimmune diseases are actually autoalloimmune or allo-autoimmune. This concept, if proven, has the potential to open up a spectrum of new therapeutic approaches to SSc and potentially other autoimmune diseases (Tyndall et al. 1998).

In the first study to test the hypothesis, significantly higher levels of FMc were found in the peripheral blood of women with SSc compared to healthy women (Nelson et al. 1998). In other studies FMc was reported in DNA extracted from skin biopsies from SSc patients but not in controls (Artlett et al. 1998). Subsequent studies that also examined skin found that FMc levels were significantly higher in SSc patients compared to controls (Ohtsuka et al. 2001; Sawaya et al. 2004). (However, the prevalence difference reported in the earlier study of skin was not corroborated, possibly in part explained by a non-quantitative technique used in the earlier study.) The mechanism by which FMc might contribute to SSc is unknown. While analogy might be invoked with GVHD an important and dramatic difference between GVHD and SSc is that hematopoietic chimerism is essentially $100 \%$ in the former vs. far less than even $1 \%$ in the latter. Thus a more likely way in which FMc might contribute to SSc is through the indirect pathway of allorecognition and by inducing immune dysregulation in the host (Nelson 1998 a,b). Further studies are needed as well as standardization of approach especially because some subsequent studies have found (Miyashita et al. 2000; Ichikawa et al. 2001; Burastero et al. 2003) while others have not found (Murata et al. 1999; Gannagé et al. 2002; SelvaO'Callaghan et al. 2003) an association of FMc with SSc.

Other investigators have examined different compartments of peripheral blood for FMc as well as cell types and functionality of FMc in SSc. An increase of FMc was found in peripheral blood mononuclear cells (PBMC), but not in plasma (Lambert et al. 2002). FMc was identified within different cellular subsets of PBMC, including T (CD3+) and B (CD19+) lymphocytes, monocytes (CD14+), and natural killer cells (CD56+/16+) (Evans et al. 1999). In salivary gland tissue, FMc was found in SSc but not in Sjögren's syndrome (Aractingi et al. 2002). In a study of autopsies FMc was found in multiple organs in women with SSc but was infrequent in controls; the most frequent site for FMc was in the spleen (Johnson et al. 2001). In localized scleroderma, male cells in skin lesions were immunophenotyped; the majority were found to be CD68+ or $\mathrm{S} 100+$, consistent with a dendritic cell phenotype. $\mathrm{T}$ and $\mathrm{B}$ lymphocytes were also represented (McNallan et al. 2007).

Overall results indicate FMc is a common phenomenon including in healthy women, but that FMc levels are increased in women with SSc. Functional studies provide additional support for a role in disease pathogenesis. In one study, PBMC from SSc patients and controls were subjected to CD28 stimulation ex vivo. In the SSc patients, but not in the controls, this stimulus prompted an increase in the amount of detectable FMc in serial samples (Burastero et al. 2003). In another investigation, T cell clones were isolated and cultured from women with SSc and control women. Expanded clones were tested for their reactivity to HLA antigens of the woman (self), and reactive clones were investi- gated further. Among SSc patients and controls, respectively, $18 \%$ and $4 \%$ of clones were found to be self-reactive, and of those, $19 \%$ and $9 \%$ were found to be of male origin. In SSc, malederived, self-reactive clones produced higher concentrations of IL-4 than did control clones, consistent with a Th2-oriented response (Scaletti et al. 2002).

While FMc may contribute to SSc in parous women, nulliparous women, men and children can also develop SSc. These populations are not subject to FMc; however, they may accrue Mc from other sources. In addition to maternal Mc, as will be discussed in more detail, other potential natural sources of Mc include prior spontaneous or induced abortion. Male DNA has been found in peripheral blood samples from some women with no history of pregnancy (Lambert et al. 2005). While unrecognized miscarriage is a potential explanation for this finding, other possible sources include acquired cells from an unrecognized (vanished) male twin or from an older brother. Supporting these possibilities, an interesting study of liver specimens from female children (recipients of liver transplant for biliary atresia or decreased from sudden infant death syndrome) and female fetuses (stillbirths or elective abortions), frequently found male Mc (Guettier et al. 2005). Thus other sources of Mc are probably common, including: early pregnancy loss, unrecognized pregnancy, twin or older sibling, and iatrogenic sources such as blood transfusion.

\section{FMc and other autoimmune diseases}

In contrast to SSc, investigations of FMc in Sjögren's syndrome have generally not supported an association, although concentrations of FMc in salivary glands have shown some predominance in Sjögren's syndrome (Mijares-Boeckh-Behrens et al. 2001; Toda et al. 2001; Endo et al. 2002; Kuroki et al. 2002; Carlucci et al. 2003). A role for FMc in systemic lupus erythematosus has also been controversial (Abbud Filho et al. 2002; Khosrotehrani et al. 2005), although several studies suggest that lupus nephritis in particular is associated with an increased concentration of FMc in circulation and in renal tissue (Mosca et al. 2003; Hovinga et al. 2006). In a case report of an autopsy of a woman with lupus, multiple organ systems were examined, and FMc was identified in all histologically abnormal tissue, although not in healthy tissue (Johnson et al. 2001).

Autoimmune thyroid disease is especially likely to manifest for the first time and flare postpartum, prompting interest in a potential role for FMc in autoimmune thyroiditis. Epidemiologic studies that have evaluated parity in risk of thyroid disease generally have not lent support for FMc in thyroiditis (Walsh et al. 2005; Pedersen etal. 2006), although results may be limited due to analyses being made according to thyroid autoantibodies rather than actual thyroid disease. FMc has been found in thyroid tissue (measured by Q-PCR and fluorescence in situ hybridization, or FISH) and was increased in autoimmune thyroid diseases compared to controls in most although not all studies (Srivatsa et al. 2001; Ando et al. 2002; Renne et al. 2004; Klintschar et al. 2006). Both Hashimoto's thyroiditis and Grave's disease have been studied. One study showed a higher FMc concentration in PMBC as well (Ando et al. 2002). In one patient, histologic evaluation showed evidence that FMc could differentiate and form normal thyroid follicular tissue (Srivatsa et al. 2001). A mouse model of experimental inflammatory thyroiditis offers additional support for a role of FMc in thyroid disease by confirming the accumulation of fetal 
cells in the maternal thyroid postpartum compared with controls (Imaizumi et al. 2002).

Primary biliary cirrhosis (PBC) is an autoimmune disease of the liver that has a very strong predilection for women in post reproductive years. PBC also resembles GVHD when the liver is affected. These observations prompted interest in a potential role of FMc in PBC. Overall, studies have consistently identified FMc in the liver of PBC patients, but many studies have not observed differences from FMc in livers of patients with other diseases (Tanaka et al. 1999; Corpechot et al. 2000; Schöniger-Hekele et al. 2002). However, some disease subsets such as women with anticentromere antibodies do seem to harbor FMc more commonly (Corpechot et al. 2000). In one study higher concentrations of FMc were described in PBC compared to controls (Fanning et al. 2000).

\section{FMc in other diseases (non autoimmune)}

A few studies have examined FMc in dermatologic disorders. The lesions of polymorphic eruptions of pregnancy have been shown to commonly contain FMc (Aractingi et al. 1998). A case of lichen planus in a female twin child (in a gender discordant dizygotic twin pair) was found to be associated with male Mc in peripheral blood and skin (Vabres et al. 2002). Two small studies of mucosal and/or cutaneous lichen planus did not consistently detect male Mc, although these were limited by size and control groups (Tanei et al. 2000; Weger et al. 2006). Similarly, limited studies in vulvar lichen sclerosis have not found a difference in FMc compared with controls (Regauer et al. 2004; Bauer et al. 2006).

While inflammatory myopathies have primarily been investigated for maternal Mc, one small study assessed a potential role of FMc in these diseases and found no association (SelvaO'Callaghan et al. 2001). A recent study of hypersensitivity pneumonitis (HP) (Kowalzick et al.) reported an association with FMc. In blood, fluid from bronchoalveolar lavage, and lung tissue from women with HP, there was a higher prevalence of FMc compared with idiopathic pulmonary fibrosis and controls (from autopsy after death from unrelated causes). Interestingly, HP patients with FMc had a significantly decreased pulmonary diffusion capacity than HP patients without FMc as well (Bustos et al. 2007).

\section{Beneficence: a role for FMc in allogeneic surveillance?}

Much of the information that is currently available derives from studies of association, and causation is unknown. It is difficult to know in studies of human biopsy or autopsy samples whether Mc is an active participant in damage, an incidental marker of concurrent processes, or a potential contributor to repair. Some studies have found evidence of fetal cell differentiation in maternal tissue suggesting they may be involved in tissue repair in a variety of different organs [56]. Other studies support a protective role for FMc in breast cancer. A role for FMc in breast cancer was explored due to the reduction in risk of breast cancer among parous women. In both an initial exploratory investigation and a confirmatory, population-based, case-control study, women with breast cancer were relatively deficient in circulating FMc compared with controls. In analyses adjusted for potential confounders, the OR for developing breast cancer in the presence of FMc was 0.29 (Gadi et al. 2007; Gadi et al. 2008). These findings support a role for FMc not previously considered: that of allogeneic surveillance. The concept evokes comparison with the graftversus-tumor effect of donor cells in hematopoietic cell transplantation. Similar studies of other cancers that are affected by parity will be of interest.

A smaller study of cervical cancer and a case report of thymic carcinoma illustrate some of the challenges in determining the role of FMc. In cervical cancer, cervical tissue in cancer cases showed FMc consistently, while tissue from healthy controls did not. The majority of the male cells were identified as either leukocytes (CD45+) or epithelium (cytokeratin positive) (Cha et al. 2003). In a case report of a woman with poorly differentiated thymic epithelial carcinoma dramatic tumor regression was observed after transfusion with G-CSF (granulocyte-colony stimulating factor)-mobilized cells from the patient's daughter. Preexisting FMc (from this daughter) was documented in the patient's circulation and was augmented in quantity after transfusion, supporting a graft-versus-tumor effect in this individual (Tokita et al. 2001).

\section{Beneficence: a role for FMc in tissue repair?}

As previously noted, fetal cells that appear to have differentiated into organ-specific phenotypes have been found in some patients with thyroid or liver damage, suggesting a role for FMc in repair (Srivatsa et al. 2001; Stevens et al. 2004). This has not yet been investigated in larger populations, although animal models may help us to better understand the phenomenon. Animal models designed to investigate FMc generally involve the breeding of females (mice or rats) with males transgenic for enhanced green fluorescent protein (EGFP). Identification of EGFP-positive cells in maternal circulation and tissues allows for identification and investigation of this fetal-derived material. One such rat model administered ethanol and gentamycin to females postpartum from a transgenic mating in order to induce hepatic and renal injury. Subsequent examination of maternal tissues identified EGFP-positive cells, presumed FMc, in maternal circulation, bone marrow, as hepatocytes in maternal liver, and as renal tubular cells in maternal kidney (Wang et al. 2004). A similar study in mice evaluated maternal tissues after postpartum exposure to chemical (carbon tetrachloride) or surgical hepatic injury (partial hepatectomy) and evaluated the involvement of FMc in response to injury. They found FMc in liver and spleen after chemical, but not surgical, exposure, with an increasing amount demonstrable over time (Khosrotehrani et al. 2007).

\section{FMc in transplantation}

Observations from transplantation studies provide clues regarding the functionality of FMc. If FMc maintains immunocompetence, its presence may influence GVHD. An increased risk of GVHD has been reported after syngeneic hematopoietic stem cell transplantation if either the donor or recipient is parous compared with nulliparous women or men (Adams et al. 2004). Further evidence comes from identification of cytotoxic $T$ cells in the circulation of parous women donors that can occur concurrently with FMc and maintain reactivity specific for minor histocompatibility $(\mathrm{H})$ antigens (Verdijk et al. 2004).

It has been speculated that long-term persistence of FMc is associated with long-term maternal tolerance to fetal antigens. Maternal tolerance to FMc could also impact transplantation 
outcomes, similar to reports of better tolerance to non-inherited maternal antigens (NIMA) in transplant recipients (Burlingham et al. 1998; Stern et al. 2008) (as will be discussed further below). The largest study addressing this question analyzed over 1800 living donor renal transplants in which parents received transplants from their offspring. They found no difference in graft survival at 3 years in the mothers than the fathers (Mahanty et al. 2001).

\section{Fetal microchimerism: summary}

Investigations beginning over a century ago revealed that transfer of fetal cells to the mother during pregnancy occurs commonly, if not uniformly. Long-term, low levels of persistent FMc are common. The presence of FMc and its differentiation potential have been demonstrated in a number of different tissues. It is likely that the consequences of persistent FMc depend on a constellation of factors including the immunogenetic relationships between mother and fetus, and perhaps between a newly acquired source of FMc and preexisting inhabitants of the maternal system (from her own mother, her prior children, or other sources). In some cases, FMc appears to contribute to perturbations in maternal immunity that may contribute to autoimmune diseases. In other situations, the context of these interactions may yield benefit to long-term maternal health by allowing FMc to act as allogeneic surveyors in her system.

\section{Maternal microchimerism}

\section{The NIMA effect}

Fetal acquisition of maternal cells may have even more dramatic consequences on later fetal health than fetomaternal transfer does on maternal health. The fetal immune response differs from adult and even from neonatal, immune responses. This was demonstrated decades ago by Billingham and colleagues in a series of experiments exposing mice and chicks to allogeneic tissue suspensions in utero. After delivery and the attainment of maturity, skin grafts from donors of the same strain, as well as additional allogeneic skin grafts, were placed. They demonstrated tolerance to the grafts from strains to which in utero exposure occurred, and rejection of unexposed grafts, suggesting enduring and specific tolerance to antigens presented to the fetus in utero (Billingham et al. 1953). Thus natural acquisition of MMc by the fetus in normal pregnancy may result in similar durable, maternal-specific tolerance, or the NIMA effect.

Identification of circulating maternal cells was first noted in offspring with severe combined immunodeficiency syndrome (Pollack et al. 1982; Geha et al. 1983). Early human data to support the NIMA effect came from the work of Claas et al., in 1988. In 26 highly-sensitized renal transplant patients (who had received earlier massive blood transfusions), permissible HLA mismatches were identified by serologic testing. A majority of these permissible mismatches included NIMAs (15/26), whereas only $2 / 26$ included non-inherited paternal antigens, or NIPAs (Claas et al. 1988). Additional studies, although not all, have described a significant correlation of NIMA with better transplantation outcomes (Burlingham et al. 1998; Stern et al. 2008).

A NIMA effect has also been suggested in some studies of autoimmune disease. For example a study that investigated patients with rheumatoid arthritis (RA) who lacked an RA-associ- ated HLA allele found a significant increase in NIMA that carried a risk allele when compared to NIPA (tenWolde et al. 1993). A similar observation was reported in type 1 diabetes (Pani et al. 2002). Interestingly, a recent study of RA patients also found protection from RA when NIMA carried an RA-protective HLA sequence (Feitsma et al. 2007). However, a difference in NIMA versus NIPA has not been uniformly found in other studies of autoimmune diseases. That a mother might influence the health of her offspring by "donating" MMc as well as subcellular organelles and macromolecules, has been termed "matrilineal nonMendelian heredity" (Maurel et al. 2008).

\section{MMc kinetics and HLA context}

To address concerns about maternal cell contamination of cord blood and potential effects thereof on cord blood transplantation, FISH was used to identify female cells in the PBMC from cord blood of healthy male fetuses. CD8+ and CD34+ subsets were similarly assessed. Overall, $20 \%$ of samples were positive for maternal cells in either unselected PBMC or one of the subsets, and the proportion of maternal to total cells was as high as 1\% (Hall et al. 1995). Lo and colleagues investigated MMc in cord blood using PCR for nonshared polymorphisms. They found that $24-42 \%$ of samples were positive for MMc, with fractional concentrations of $2.6 \times 10^{-4}$ in the cellular fraction, and $3.0 \times 10^{-}$ 3 in plasma (Lo et al. 1996; Lo et al. 2000).

The long-term persistence of MMc in immunologically competent adults was queried in a study of healthy adults and patients with SSc. $55 \%$ of patients were found to harbor MMc in PBMC isolated from a single peripheral blood draw by PCR techniques identifying nonshared HLA polymorphisms; the mean age at the time of blood draw was 28 years. This study used a non-quantitative technique, so differences in levels could not be analyzed; however there was no difference in prevalence observed in healthy adults and SSc patients.(Maloney et al. 1999)

The effect of specific HLA alleles and of HLA-compatibility between individuals and their mothers has been analyzed for an effect on MMc. In cord blood collected at a median of 26 weeks gestation by cordocentesis performed for clinical indications, MMc was identified in $53 \%$ of specimens. HLA genotyping was performed for mother-fetus pairs, and MMc was found to be associated with maternal-fetal compatibility at the DRB1 and DQB1 loci, as well as with the maternal DQB1 ${ }^{*} 0301$ allele (Berry et al. 2004).

Animal models have shown that transfusion of parental lymphocytes homozygous for major histocompatibility (MHC) into heterozygous offspring can result in a lupus-like picture in the offspring (Portanova et al. 1988). Because of this observation, Stevens and colleagues sought to assess mother/son HLA compatibility in male subjects with lupus compared with controls. They found that bidirectional compatibility for DRB1 was associated with lupus (odds ratio 5.0). Together these observations suggest MMc could sometimes contribute to lupus in a woman's offspring (Stevens et al. 2005).

A mouse model system designed to assess the relationship between MHC compatibility and MMc found that MMc was increased in homozygous progeny compared with heterozygous progeny (Kaplan et al. 2005). As with FMc, the nature of MMc acquisition in the fetus may depend on the larger context of histocompatibility in the pregnancy within which transplacental 

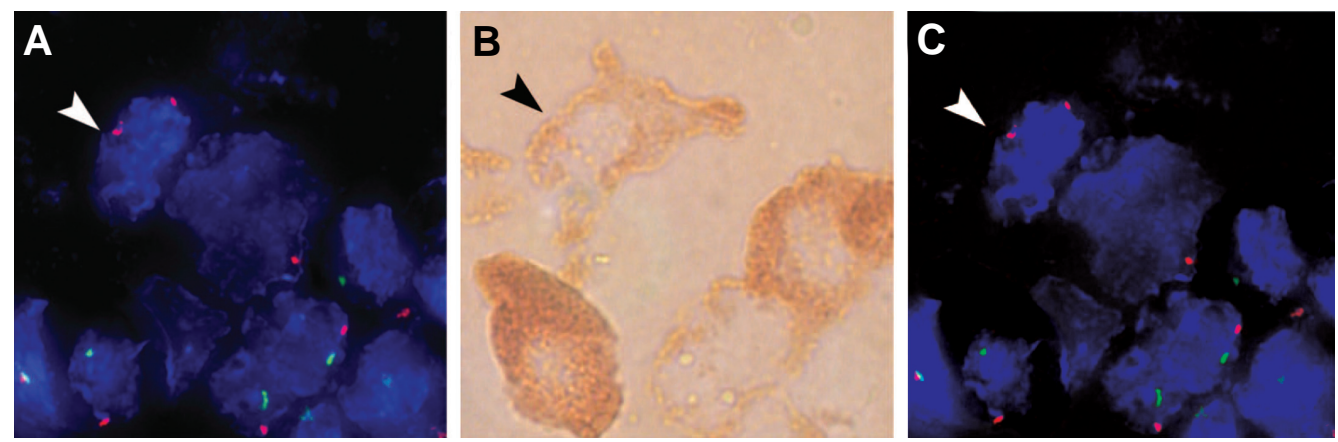

et al. 1996). In another study, female mice transgenic for luciferase were crossed with wild type males, and wild type offspring were assessed for luciferase signal (acquired via MMc). MMc was demonstrated in $85 \%$ of mice and was widely distributed, with highest concentrations noted in offspring heart and lung (Su et al. 2008).

The functionality of MMc is supported by the difficulty investigators have had in establishing an IL-2 knockout mouse, which has been a model sought to better understand the role of IL-2 in thymic development. Attempts to create such a with concomitant FISH for $X$ and $Y$ chromosomes. (A) Fluorescence microscopy showing a fem among male cells. (B) Light microscopy of the same cells pictured in (A); the red-brown staining identifies $\beta$ cell insulin expression. (C) Overlay of $(A, B)$ showing identical cells by both FISH and immunohistochemistry; reproduced with permission from Proc. Natl. Acad. Sci. USA (2007) 104:1640.

trafficking occurred.

\section{Long-term persistent MMc and its functional capacity}

To begin to elucidate the functional capacity of MMc, a number of studies have investigated fetal and neonatal tissues to determine the distribution of maternal cells. In fetal tissues obtained from pregnancy terminations performed for either social reasons or anomalies, or stillbirth (14-27 weeks gestation), maternal cells were identified in multiple tissues and PBMC subset populations. Specifically, MMc has been found in fetal liver, lung, heart, thymus, spleen, adrenal, kidney, pancreas, brain, and gonads. Cell subsets that have been found to harbor MMc include CD3+, CD19+, CD34+, and CD45+ (Gotherstrom et al. 2005; Jonsson et al. 2008). Neonatal tissue studies have confirmed similar results (Srivatsa etal.2003). The ability of MMc to differentiate into a local phenotype in an organ to which it migrates is evidenced by work in neonatal lupus (Stevens et al. 2003), type 1 diabetes (see Fig. 3) (Nelson et al. 2007), and juvenile inflammatory dermatoses (Khosrotehrani et al. 2005), as explained in more detail below.

Beyond the fetal and neonatal period, the long-term persistence of MMc in healthy adults has been demonstrated. $\mathrm{MMc}$ is detectable in circulating T cells (CD3+), B cells (CD19+), monocyte/macrophages (CD14+), and NK cells (CD56/CD16+), in adults (mean age 39 years). In this study $39 \%$ of all tested subjects had detectable MMc in at least one subset (Loubiere et al. 2006).

Animal models can provide insight into the trafficking and functionality of MMc. In a rat model trafficking of mesenchymal stem cells injected into maternal circulation across the placenta to the fetus was found to depend on placental integrins and a maternal to fetal vascular endothelial growth factor-A (VEGF-A) concentration gradient. In this study, the cells engrafted in fetal tissues and persisted for several weeks (Chen et al. 2008). Other mouse models have confirmed the near ubiquity of maternal to fetal transfer and have suggested that such trafficking commences with the establishment of placental circulation. In addition, one study utilizing blastocyst transfer of specific fetuses showed that the distribution of MMc was altered depending on the immune status of the fetus. In immune-deficient offspring (scid/ scid), initial localization of MMc occurred within the thymus, followed by subsequent broad distribution. In immune competent offspring, MMc localized specifically to the bone marrow (Piotrowski model have been confounded by acquisition by the IL-2 knockout fetus of maternal IL-2 expressing cells. These offspring develop chimerism for IL-2 knockout cells and IL-2 expressing cells, resulting in detectable IL-2 that prevents any abnormalities in development and precludes evaluation of the knockout phenotype (Wrenshall et al. 2007).

\section{Therapeutic potential of in utero stem cell transfusion}

Other work has sought to exploit the tolerogenic nature of in utero antigenic exposure and the development of persistent Mc for the treatment of genetic diseases. A few case reports of successful engraftment and persistent functional donor Mc after delivery have been reported in diseases such as hemoglobinopathies and severe immunodeficiencies. (reviewed in (Surbek et al. 1999)) However, both these human reports, as well as data from animal models have yielded conflicting data regarding efficacy and feasibility (Carrier et al. 2000; Garbuzova-Davis et al. 2006). Factors that may influence the success of in utero transplantation include the timing, route of administration, and donor characteristics. Earlier transplantation may be more likely to result in engraftment due to the relative immaturity of the fetal immune system. On the other hand, intravenous administration via cordocentesis is likely to be more efficient than peritoneal administration. A variety of donor sources have been considered, including paternal bone marrow. Because there is natural acquisition of MMc during fetal life early in pregnancy, successful transplant might be more readily achievable with the mother as a donor, taking advantage of pre-established tolerance through very early natural acquisition might permit efficient intravenous delivery of a larger cell dose.

\section{MMc, malevolence or beneficence?}

Malevolence: alloimmunity underlying some autoimmunity?

MMc may have the potential to generate an alloimmune response in the "fetal" host over time, manifesting in classic autoimmune disease findings. A case report suggesting such a phenomenon described dermatologic and systemic autoimmune manifestations in a child who had significant MMc within his CD4+ lymphocyte population (Kowalzick et al. 2005). MMc was found significantly more often in women with SSc than controls in PBMC. In this study, one patient with severe SSc who tested negatively for MMc in PBMC subsequently died following an 
autologous hematopoietic cell transplant and was found to harbor substantial levels of MMc in multiple tissues including lung, heart and bone marrow (Lambert et al. 2004).

Neonatal lupus syndrome is a congenital autoimmune disease associated with congenital heart block, rash, and hepatic and hematologic abnormalities. While specific maternal autoantibodies are associated with the disease, only a small proportion of babies born to women with these antibodies develop the manifestations, suggesting that other factors are necessary parts of the pathogenesis. Stevens and colleagues demonstrated increased $\mathrm{MMc}$ in the hearts of patients with neonatal lupus syndrome compared with controls. The majority of maternal cells identified expressed $\alpha$-actin, a cardiomyocyte specific marker (Stevens et al. 2003). Stevens and colleagues also evaluated MMc in peripheral blood from twins and triplets discordant for neonatal lupus syndrome or congenital heart block. MMc was found in children both with and without congenital heart block. In one family, the concentration of MMc increased over time in a child who developed progressive congenital heart block (Stevens et al. 2005).

Other autoimmune diseases that primarily affect children have been subjects of investigation of a potential role for MMc in autoimmunity, including inflammatory myopathies and biliary atresia. An increase in MMc has been found in juvenile idiopathic inflammatory myopathy and dermatomyositis in peripheral blood and also in muscle tissue when compared with controls (Artlett et al. 2000; Reed et al. 2000). One study showed a negative association of MMc with methotrexate therapy (Artlett etal. 2001). In the juvenile cutaneous inflammatory disease pityriasis lichenoides, higher concentrations of MMc were found in skin compared with healthy controls and with noninflammatory skin lesions. In this study, MMc was found to express cytokeratin, suggestive of differentiation into keratinocytes (Khosrotehrani et al. 2005). Biliary atresia is a progressive disease of the biliary tree in infants that is the most common cause of pediatric liver transplantation in the United States. Two studies found MMc in the livers of patients with biliary atresia and not in controls (Suskind et al. 2004; Kobayashi et al. 2007). Further mechanistic and functional investigations are needed to better understand the role of MMc in the development of these pediatric diseases.

Infantile hemangiomas have also been investigated and have not been found to contain MMc (Pittman et al. 2006; Regnier et al. 2007). A study of twins showed increased peripheral blood Mc (from multiple sources, possibly including MMc) in multiple sclerosis, comparing dizygotic affected twins versus their unaffected co-twins, with even higher prevalence of Mc in monozygotic twin pairs concordant for the disease (Willer et al. 2006).

\section{MMc benevolence: tissue repair or cooperative contribution?}

Higher prevalence and concentrations of MMc in disease states in peripheral blood and in tissue could be interpreted a number of different ways. One possibility is that the MMc is contributing to the disease in a pathogenic role, for example as effector cells against host tissues. Another possibility, also in a pathogenic role, is that differentiated MMc in tissues are the target of immunologic attack. However, there are other explanations that invoke a positive role. MMc could travel secondarily to a diseased organ and contribute to tissue repair. Additionally, MMc could provide a type of "educational" advantage and cooperatively contribute for example in the development of a normal fetus and neonate.

In a study of type 1 diabetes MMc was significantly increased in peripheral blood when compared to unaffected siblings and to unrelated controls. A few pancreases were also studied for MMc and to characterize cell type for any maternal cells that might be present. Very few hematopoietic cells were found in the 4 pancreases studied, but MMc was not uncommon among islet $\beta$ cells and were somewhat more numerous in the type 1 diabetic pancreas. The role of MMc in type 1 diabetes is not known but overall a beneficial role was suggested as the cells secreted insulin and could be attempting to help to regenerate diseased tissue (Nelson et al. 2007).

\section{Maternal microchimerism: summary}

The exchange of material between mother and fetus is bidirectional, but the implications of MMc acquired by the fetus in utero differ fundamentally from FMc acquired by the mother in adult life. Because this exposure occurs during early development of the fetal immune system, the primary response is to develop allospecific tolerance to maternal antigens. Long-term persistence of MMc reflects the importance of matrilineal influences on health that occur through non-genetic acquisition of cellular and subcellular material and can alter immune function and responsiveness. Similar to FMc, MMc is common, seems to have both beneficial and detrimental effects on the host, and may contribute in a cooperative role to the differentiation and functionality of host cells. Furthering our understanding of the unique tolerogenic nature of the fetal response to MMc exposure may have important therapeutic relevance.

\section{References}

ABBUd FILHO, M., PAVARINO-BERTElli, E.C., ALVARENGA, M.P.S., FERNANDES, I.M.M., TOLEDO, R.A., TAJARA, E.H., SAVOLDI-BARBOSA, M., GOLDMANN, G.H. and GOLONI-BERTOLLO, E.M. (2002). Systemic lupus erythematosus and microchimerism in autoimmunity. Transplant Proc 34:2951 2952.

ADAMS, K.M., HOLMBERG, L.A., LEISENRING, W., FEFER, A., GUTHRIE, K.A., TYLEE, T.S., MCDONALD, G.B., BENSINGER, W.I. and NELSON, J.L. (2004). Risk factors for syngeneic graft-versus-host disease after adult hematopoietic cell transplantation. Blood 104: 1894-1897.

ADAMS, K.M., LAMBERT, N.C., HEIMFELD, S., TYLEE, T.S., PANG, J.M., ERICKSON, T.D. and NELSON, J.L. (2003). Male DNA in female donor apheresis and CD34-enriched products. Blood 102: 3845-3847.

ADAMS, K.M., YAN, Z., STEVENS, A.M. and NELSON, J.L. (2007). The Changing Maternal «Self» Hypothesis: A Mechanism for Maternal Tolerance of the Fetus. Placenta 28: 378-382.

AL-MUFTI, R., LEES, C., ALBAIGES, G., HAMBLEY, H. and NICOLAIDES, K.H. (2000). Fetal cells in maternal blood of pregnancies with severe fetal growth restriction. Hum Reprod 15: 218-221.

ANDO, T., IMAIZUMI, M., GRAVES, P.N., UNGER, P. and DAVIES, T.F. (2002). Intrathyroidal Fetal Microchimerism in Graves' Disease. J Clin Endocrinol Metab 87: 3315-3320.

ARACTINGI, S., BERKANE, N., BERTHEAU, P., GOUÉ, C.L., DAUSSET, J., UZAN, S. and CAROSELLA, E.D. (1998). Fetal DNA in skin of polymorphic eruptions of pregnancy. Lancet352: 1898-1901.

ARACTINGI, S., SIBILIA, J., MEIGNIN, V., LAUNAY, D., HACHULLA, E., DANFF, C.L., JANIN, A. and MARIETTE, X. (2002). Presence of microchimerism in labial salivary glands in systemic sclerosis but not in Sjögren's syndrome. Arthritis Rheum 46: 1039-1043.

ARIGA, H., OHTO, H., BUSCH, M.P., IMAMURA, S., WATSON, R., W REED, W. and LEE, T.H. (2001). Kinetics of fetal cellular and cell-free DNA in the maternal 
circulation during and after pregnancy: implications for noninvasive prenatal diagnosis. Transfusion 41: 1524-1530.

ARTLETT, C., O'HANLON, T., LOPEZ, A., SONG, Y., MILLER, F. and RIDER, L. (2003). HLA-DQA1 is not an apparent risk factor for microchimerism in patients with various autoimmune diseases and in healthy individuals. Arthritis Rheum 48: 2567-2572.

ARTLETT, C.M., MILLER, F.W., RIDER, L.G. and GROUP, C.M.H.C.S. (2001). Persistent maternally derived peripheral microchimerism is associated with the juvenile idiopathic inflammatory myopathies. Rheumatology 40: 1279-1284.

ARTLETT, C.M., RAMOS, R., JIMINEZ, S.A., PATTERSON, K., MILLER, F.W. and RIDER, L.G. (2000). Chimeric cells of maternal origin in juvenile idiopathic inflammatory myopathies. Lancet 356: 2155-2156.

ARTLETT, C.M., SMITH, J.B. and JIMENEZ, S.A. (1998). Identification of Fetal DNA and Cells in Skin Lesions from Women with Systemic Sclerosis. NEng/J Med338: 1186-1191.

BAUER, M., WEGER, W., ORESCOVIC, I., HIEBAUM, E.M., BENEDICIC, C., LANG, U., PERTL, C. and PERTL, B. (2006). Fetal microchimerism is not involved in the pathogenesis of lichen sclerosus of the vulva. Prenat Diagn 26: 175-178.

BAYES-GENIS, A., BELLOSILLO, B., DELACALLE, O., SALIDO, M., ROURA, S., RISTOL, F.S., SOLER, C., MARTINEZ, M., ESPINET, B., SERRANO, S., DELUNA, A.B. and CINCA, J. (2005). Identification of Male Cardiomyocytes of Extracardiac Origin in the Hearts of Women with Male Progeny: Male Fetal Cell Microchimerism of the Heart. J Heart Lung Transplant 24: 2179-2183.

BERRY, S.M., HASSAN, S.S., RUSSELL, E., KUKURUGA, D., LAND, S. and KAPLAN, J. (2004). Association of maternal histocompatibility at Class II loci with maternal microchimerism in the fetus. Pediatr Res 56: 73-78.

BIANCHI, D.W., FARINA, A., WEBER, W., DELLI-BOVI, L.C., DERISO, M., WILLIAMS, J.M. and KLINGER, K.W. (2001). Significant fetal-maternal hemorrhage after termination of pregnancy: Implications for development of fetal cell microchimerism. Am J Obstet Gynecol 184: 703-706.

BIANCHI, D.W., FLINT, A.F., PIZZIMENTI, M.F., KNOLL, J.H.M. and LATT, S.A. (1990). Isolation of Fetal DNA from Nucleated Erythrocytes in Maternal Blood. Proc Natl Acad Sci USA 87: 3279-3283.

BIANCHI, D.W., WILLIAMS, J.M., SULLIVAN, L.M., HANSON, F.W., KLINGER, K.W. and SHUBER, A.P. (1997). PCR Quantitation of Fetal Cells in Maternal Blood in Normal and Aneuploid Pregnancies. Am J Hum Genet 61: 822-829.

BIANCHI, D.W., ZICKWOLF, G.K., WEIL, G.J., SYLVESTER, S. and DEMARIA, M. (1996). Male fetal progenitor cells persist in maternal blood for as long as 27 years postpartum. Proc Nat/ Acad Sci USA 93: 705-708.

BILLINGHAM, R.E., BRENT, L. and MEDAWAR, P.B. (1953). Actively Acquired Tolerance of Foreign Cells. Nature 172: 603-606.

BONNEY, E.A. and MATZINGER, P. (1997). The maternal immune system's interaction with circulating fetal cells. J Immuno/ 158: 40-47.

BURASTERO, S.E., GALBIATI, S., VASSALLO, A., SABBADINI, M.G., BELLONE, M., MARCHIONNI, L., SMID, M., FERRERO, E., FERRARI, A., FERRARI, M. and CREMONESI, L. (2003). Cellular microchimerism as a lifelong physiologic status in parous women: An immunologic basis for its amplification in patients with systemic sclerosis. Arthritis Rheum 48: 1109-1116.

BURLINGHAM, W.J., GRAILER, A.P., HEISEY, D.M., CLAAS, F.H.J., NORMAN, D., MOHANAKUMAR, T., BRENNAN, D.C., DEFIJTER, H., VANGELDER, T., PIRSCH, J.D., SOLLINGER, H.W. and BEAN, M.A. (1998). The Effect of Tolerance to Noninherited Maternal HLA Antigens on the Survival of Renal Transplants from Sibling Donors. N Eng/J Med339: 1657-1664.

BUSTOS, M.L., FRIAS, S., RAMOS, S., ESTRADA, A., ARREOLA, J.L., MENDOZA, F., GAXIOLA, M., SALCEDO, M., PARDO, A. and SELMAN, M. (2007). Local and Circulating Microchimerism Is Associated with Hypersensitivity Pneumonitis. Am J Respir Crit Care Med 176: 90-95.

CARLUCCI, F., PRIORI, R. and VALESINI, G. (2003). Microchimerism in Sjogren's syndrome. Rheumatology 42: 486-487.

CARRIER, E., GILPIN, E., LEE, T.H., BUSCH, M.P. and ZANETTI, M. (2000). Microchimerism does not induce tolerance after in utero transplantation and may lead to the development of alloreactivity. J Lab Clin Med 136: 224-235.

CHA, D., KHOSROTEHRANI, K., KIM, Y., STROH, H., BIANCHI, D.W. and JOHNSON, K.L. (2003). Cervical Cancer and Microchimerism. Obstet Gynecol 102: $774-781$.
CHEN, C.P., LEE, M.Y., HUANG, J.P., APLIN, J.D., WU, Y.H., HU, C.S., CHEN, P.C., LI, H., HWANG, S.M., LIU, S.H. and CYANG, Y. (2008). Trafficking of Multipotent Mesenchymal Stromal Cells from Maternal Circulation Through the Placenta Involves Vascular Endothelial Growth Factor Receptor-1 and Integrins. Stem Cells 26: 550-561.

CHIU, R.W.K., POON, L.L.M., LAU, T.K., LEUNG, T.N., WONG, E.M.C. and LO, Y.M.D. (2001). Effects of blood-processing protocols on fetal and total DNA quantification in maternal plasma. Clin Chem 47: 1607-1613.

CLAAS, F.H.J., GIJBELS, Y., VANDERVELDEN-DEMUNCK, J. and ROOD, J.J.V. (1988). Induction of B Cell Unresponsiveness to Noninherited Maternal HLA Antigens during Fetal Life. Science 241: 1815-1817.

CORPECHOT, C., BARBU, V., CHAZOUILLÈRES, O. and POUPON, R. (2000). Fetal microchimerism in primary biliary cirrhosis. $J$ Hepato/33: 696-700.

COX, L.A., RAMOS, R.C., DENNIS, T.N., JIMENEZ, S.A., SMITH, J.B. and ARTLETT, C.M. (2003). Detection of microchimeric cells in the peripheral blood of nonpregnant women is enhanced by magnetic cell sorting before PCR. Clin Chem 49: 309-312.

ENDO, Y., NEGISHI, I. and ISHIKAWA, O. (2002). Possible contribution of microchimerism to the pathogenesis of Sjogren's syndrome. Rheumatology 41 : 490-495

EVANS, P.C., LAMBERT, N., MALONEY, S., FURST, D.E., MOORE, J.M. and NELSON, J.L. (1999). Long-Term Fetal Microchimerism in Peripheral Blood Mononuclear Cell Subsets in Healthy Women and Women With Scleroderma. Blood 93: 2033-2037.

FANNING, P.A., JONSSON, J.R., CLOUSTON, A.D., EDWARDS-SMITH, C., BALDERSON, G.A., MACDONALD, G.A., CRAWFORD, D.H.G., KERLIN, P., POWELL, L.W. and POWELL, E.E. (2000). Detection of male DNA in the liver of female patients with primary biliary cirrhosis. J Hepato/33: 690-695.

FEITSMA, A.L., WORTHINGTON, J., VANDERHELM-VANMIL, A.H.M., PLANT, D., THOMSON, W., URSUM, J., SCHAARDENBURG, D.V., VANDERHORSTBRUINSMA, I.E., VANROOD, J.J., HUIZINGA, T.W.J., TOES, R.E.M. and DEVRIES, R.R.P. (2007). Protective effect of noninherited maternal HLA-DR antigens on rheumatoid arthritis development. Proc Natl Acad Sci USA 104 19966-19970.

FREEDMAN, W.L. and MCMAHON, F.J. (1960). Placental metastasis. Review of the literature and report of a case of metastatic melanoma. Obstet Gyneco/16: 550-560.

GADI, V.K., MALONE, K.E., GUTHRIE, K.A., PORTER, P.L. and NELSON, J.L. (2008). Case-Control Study of Fetal Microchimerism and Breast Cancer. PLOS One 3: e1706

GADI, V.K. and NELSON, J.L. (2007). Fetal Microchimerism in Women with Breast Cancer. Cancer Res 67: 9035-9038.

GANNAGÉ, M., AMOURA, Z., LANTZ, O., PIETTE, J.C. and CAILLAT-ZUCMAN, S. (2002). Feto-maternal microchimerism in connective tissue diseases. EurJ Immuno/32: 3405-3413

GARBUZOVA-DAVIS, S., GOGRAFE, S.J., SANBERG, C.D., WILLING, A.E., SAPORTA, S., CAMERON, D.F., DESJARLAIS, T., DAILY, J., KUZMINNICHOLS, N., CHAMIZO, W., KLASKO, S.K. and SANBERG, P.R. (2006) Maternal transplantation of human umbilical cord blood cells provides prenatal therapy in Sanfilippo type B mouse model. FASEB J. 05-4684fje.

GEHA, R.S. and REINHERZ, E. (1983). Identification of circulating maternal T and B lymphocytes in uncomplicated severe combined immunodeficiency by HLA typing of subpopulations of $T$ cells separated by the fluorescence-activated cell sorter and of Epstein Barr virus-derived B cell lines. J/mmuno/130: 2493-2495.

GOTHERSTROM, C., JOHNSSON, A.M., MATTSSON, J., PAPADOGIANNAKIS N. and WESTGREN, M. (2005). Identificantion of maternal hematopoietic cells in a 2nd-trimester fetus. Fetal Diagn Ther20: 355-358.

GUETTA, E., GORDON, D., SIMCHEN, M.J., GOLDMAN, B. and BARKAI, G. (2003). Hematopoietic progenitor cells as targets for non-invasive prenatal diagnosis: detection of fetal CD34+ cells and assessment of post-delivery persistence in the maternal circulation. Blood Cells Mol Dis 30: 13-21.

GUETTIER, C., SEBAGH, M., BUARD, J., FENEUX, D., ORTIN-SERRANO, M., GIGOU, M., TRICOTTET, V., REYNĖS, M., SAMUEL, D. and FÉRAY, C. (2005). Male cell microchimerism in normal and diseased female livers from fetal life to adulthood. Hepatology 42: 35-43.

HALL, J.M., LINGENFELTER, P., ADAMS, S.L., LASSER, D., HANSEN, J.A. and 
BEAN, M.A. (1995). Detection of maternal cells in human umbilical cord blood using fluorescence in situ hybridization. Blood 86: 2829-2832.

$\mathrm{HENCH}$, P.S. (1938). The ameliorating effect of pregnancy on chronic atropic infections rheumatoid arthritis, fibrosititis and intermittent hydrarthrosis. Proc Staff Meet Mayo Clin 13: 161-175.

HERZENBERG, L.A., BIANCHI, D.W., SCHRODER, J., CANN, H.M. and IVERSON, G.M. (1979). Fetal Cells in the Blood of Pregnant Women: Detection and Enrichment by Fluorescence-Activated Cell Sorting. Proc Natl Acad Sci USA 76: 1453-1455.

HOLZGREVE, W., GHEZZI, F., DINARO, E., GANSHIRT, D., MAYMON, E. and HAHN, S. (1998). Disturbed feto-maternal cell traffic in preeclampsia. Obstet Gyneco/91: 669-672.

HOVINGA, I.C.L.K., KOOPMANS, M., BAELDE, H.J., VANDERWAL, A.M., SIJPKENS, Y.W.J., DEHEER, E., BRUIJN, J.A. and BAJEMA, I.M. (2006). Chimerism occurs twice as often in lupus nephritis as in normal kidneys. Arthritis Rheum 54: 2944-2950.

ICHIKAWA, N., KOTAKE, S., HAKODA, M. and KAMATANI, N. (2001). Microchimerism in Japanese patients with systemic sclerosis. Arthritis Rheum 44: 1226-1228.

IMAIZUMI, M., PRITSKER, A., UNGER, P. and DAVIES, T.F. (2002). Intrathyroidal Fetal Microchimerism in Pregnancy and Postpartum. Endocrinology 143: 247253.

INVERNIZZI, P., BIONDI, M., BATTEZZATI, P., PEREGO, F., SELMI, C., CECCHINI, F., PODDA, M. and SIMONI, G. (2002). Presence of fetal DNA in maternal plasma decades after pregnancy. Hum Genet 110: 587-591.

JIMENEZ, D.F., LEAPLEY, A.C., LEE, C.I., ULTSCH, M.-N. and TARANTAL, A.F. (2005). Fetal CD34+ Cells in the Maternal Circulation and Long-Term Microchimerism in Rhesus Monkeys (Macaca mulatta). Transplantation 79: 142-146.

JIMENEZ, D.F. and TARANTAL, A.F. (2003). Quantitative Analysis of Male Fetal DNA in Maternal Serum of Gravid Rhesus Monkeys (Macaca mulatta). Pediatr Res 53: 18-23.

JOHNSON, K., NELSON, J., FURST, D., MCSWEENEY, P., ROBERTS, D., ZHEN, D. and BIANCHI, D. (2001). Fetal cell microchimerism in tissue from multiple sites in women with systemic sclerosis. Arthritis Rheum 44: 1848-1854.

JOHNSON, K.L., MCALINDON, T.E., MULCAHY, E. and BIANCHI, D.W. (2001). Microchimerism in a female patient with systemic lupus erythematosus. Arthritis Rheum 44: 2107-2111.

JONSSON, A.M., UZUNEL, M., GOTHERSTROM, C., PAPADOGIANNAKIS, N. and WESTGREN, M. (2008). Maternal microchimerism in human fetal tissues. Am J Obstet Gyneco/198: 325.e1-325.e6.

KAPLAN, J. and LAND, S. (2005). Influence of Maternal-Fetal Histocompatibility and MHC Zygosity on Maternal Microchimerism. $J$ Immuno/174: 7123-7128.

KHOSROTEHRANI, K., GUEGAN, S., FRAITAG, S., OSTER, M., DEPROST, Y., BODEMER, C. and ARACTINGI, S. (2005). Presence of Chimeric Maternally Derived Keratinocytes in Cutaneous Inflammatory Diseases of Children: The Example of Pityriasis Lichenoides. J Invest Dermato/126: 345-348.

KHOSROTEHRANI, K., JOHNSON, K.L., CHA, D.H., SALOMON, R.N. and BIANCHI, D.W. (2004). Transfer of Fetal Cells With Multilineage Potential to Maternal Tissue. JAMA 292: 75-80.

KHOSROTEHRANI, K., JOHNSON, K.L., GUEGAN, S., STROH, H. and BIANCHI, D.W. (2005). Natural history of fetal cell microchimerism during and following murine pregnancy. J Reprod Immuno/66: 1-12.

KHOSROTEHRANI, K., LEDUC, M., BACHY, V., HUU, S.N., OSTER, M., ABBAS, A., UZAN, S. and ARACTINGI, S. (2008). Pregnancy Allows the Transfer and Differentiation of Fetal Lymphoid Progenitors into Functional T and B Cells in Mothers. J Immuno/180: 889-897.

KHOSROTEHRANI, K., MERY, L., ARACTINGI, S., BIANCHI, D.W. and JOHNSON, K.L. (2005). Absence of fetal cell microchimerism in cutaneous lesions of lupus erythematosus. Ann Rheum Dis 64: 159-160.

KHOSROTEHRANI, K., REYES, R.R., JOHNSON, K.L., FREEMAN, R.B., SALOMON, R.N., PETER, I., STROH, H., GUEGAN, S. and BIANCHI, D.W. (2007). Fetal cells participate over time in the response to specific types of murine maternal hepatic injury. Hum Reprod 22: 654-661.

KIARASH KHOSROTEHRANI, K.L.J.J.L.A.D.D.H.C.D.W.B. (2003). The influence of fetal loss on the presence of fetal cell microchimerism: A systematic review.
Arthritis Rheum 48: 3237-3241.

KLINTSCHAR, M., IMMEL, U.D., KEHLEN, A., SCHWAIGER, P., MUSTAFA, T., MANNWEILER, S., REGAUER, S., KLEIBER, M. and HOANG-VU, C. (2006). Fetal microchimerism in Hashimoto's thyroiditis: a quantitative approach. Eur $J$ Endocrino/154: 237-241.

KOBAYASHI, H., TAMATANI, T., TAMURA, T., KUSAFUKA, J., YAMATAKA, A. LANE, G.J., KAWASAKI, S., ISHIZAKI, Y., MIZUTA, K., KAWARASAKI, H. and GITTES, G.K. (2007). Maternal microchimerism in biliary atresia. JPediatr Surg 42: $987-991$.

KOLIALEXI, A., TSANGARIS, G.T., ANTSAKLIS, A. and MAVROUA, A. (2004). Rapid Clearance of Fetal Cells from Maternal Circulation after Delivery. $A n n N$ $Y$ Acad Sci1022: 113-118.

KOOPMANS, M., HOVINGA, I.C.L.K., BAELDE, H.J., FERNANDES, R.J., DEHEER, E., BRUIJN, J.A. and BAJEMA, I.M. (2005). Chimerism in Kidneys, Livers and Hearts of Normal Women: Implications for Transplantation Studies. $A m J$ Transplant 5: 1495-1502.

KOOPMANS, M., HOVINGA, I.C.L.K., BAELDE, H.J., HARVEY, M.S., DEHEER, E., BRUIJN, J.A. and BAJEMA, I.M. (2008). Chimerism occurs in thyroid, lung, skin and lymph nodes of women with sons. J Reprod Immuno/78: 68-75.

KOWALZICK, L., ARTLETT, C., THISS, K., BAUM, H., ZIEGLER, H., MISCHKE, D., BLUM, R., PONNIGHAUS, J. and QUIETSCH, J. (2005). Chronic graft-versushost-disease-like dermopathy in a child with CD4+cell microchimerism. Dermatology 210: 68-71.

KOWALZICK, L., ARTLETT, C.M., THISS, K., BAUM, H.P., ZIEGLER, H., MISCHKE, D., BLUM, R., PONNIGHAUS, J.M. and QUIETSCH, J. (2005). Chronic graftversus-host-disease-like dermopathy in a child with CD4+ cell microchimerism. Dermatology 210: 68-71.

KUROKI, M., OKAYAMA, A., NAKAMURA, S., SASAKI, T., MURAI, K., SHIBA, R., SHINOHARA, M. and TSUBOUCHI, H. (2002). Detection of maternal-fetal microchimerism in the inflammatory lesions of patients with Sjogren's syndrome. Ann Rheum Dis 61: 1041-1046.

LAMBERT, N.C., ERICKSON, T.D., YAN, Z., PANG, J.M., GUTHRIE, K.A., FURST, D.E. and NELSON, J.L. (2004). Quantification of maternal microchimerism by HLA-specific real-time polymerase chain reaction: Studies of healthy women and women with scleroderma. Arthritis Rheum 50: 906-914.

LAMBERT, N.C., LO, Y.M.D., ERICKSON, T.D., TYLEE, T.S., GUTHRIE, K.A., FURST, D.E. and NELSON, J.L. (2002). Male microchimerism in healthy women and women with scleroderma: cells or circulating DNA? A quantitative answer. Blood100: 2845-2851.

LAMBERT, N.C., PANG, J.M., YAN, Z., ERICKSON, T.D., STEVENS, A.M. FURST, D.E. and NELSON, J.L. (2005). Male microchimerism in women with systemic sclerosis and healthy women who have never given birth to a son. Ann Rheum Dis 64: 845-848.

LAPAIRE, O., HOLZGREVE, W., OOSTERWIJK, J.C., BRINKHAUS, R. and BIANCHI, D.W. (2007). Georg Schmorl on Trophoblasts in the Maternal Circulation. Placenta 28: 1-5.

LAU, T.K., LO, K.W.K., CHAN, L.Y.S., LEUNG, T.Y. and LO, Y.M.D. (2000). Cellfree fetal deoxyribonucleic acid in maternal circulation as a marker of fetalmaternal hemorrhage in patients undergoing external cephalic version near term. Am J Obstet Gynecol 183: 712-716.

LAU, T.W., LEUNG, T.N., CHAN, L.Y.S., LAU, T.K., CHAN, K.C.A., TAM, W.H. and LO, Y.M.D. (2002). Fetal DNA clearance from maternal plasma is impaired in preeclampsia. Clin Chem 48: 2141-2146.

LEE, T.H., MONTALVO, L., CHREBTOW, V. and BUSCH, M.P. (2001). Quantitation of genomic DNA in plasma and serum samples: higher concentrations of genomic DNA found in serum than in plasma. Transfusion 41: 276-282.

LEUNG, T.N., ZHANG, J., LAU, T.K., HJELM, N.M. and LO, Y.M.D. (1998). Maternal plasma fetal DNA as a marker for preterm labour. Lancet352: 19041905.

LO, Y., LAU, T., CHAN, L., LEUNG, T. and CHANG, A. (2000). Quantitative analysis of the bidirectional fetomaternal transfer of nucleated cells and plasma DNA. Clin Chem 46: 1301-1309.

LO, Y., LAU, T., ZHANG, J., LEUNG, T., CHANG, A., HJELM, N., ELMES, R. and BIANCHI, D. (1999). Increased fetal DNA concentrations in the plasma of pregnant women carrying fetuses with Trisomy 21. Clin Chem 45: 1747-1751.

LO, Y., LEUNG, T., TEIN, M., SARGENT, I., ZHANG, J., LAU, T., HAINES, C. and 
REDMAN, C. (1999). Quantitative abnormalities of fetal DNA in maternal serum in preeclampsia. Clin Chem 45: 184-188.

LO, Y., TEIN, M., LAU, T., HAINES, C., LEUNG, T., POON, P., WAINSCOAT, J., JOHNSON, P., CHANG, A. and HJELM, N. (1998). Quantitative analysis of fetal DNA in maternal plasma and serum: Implications for noninvasive prenatal diagnosis. Am J Hum Genet 62: 768-775.

LO, Y.M., LO, E.S., WATSON, N., NOAKES, L., SARGENT, I.L., THILAGANATHAN, B. and WAINSCOAT, J.S. (1996). Two-way cell traffic between mother and fetus: biologic and clinical implications. Blood 88: 4390-4395.

LO, Y.M.D., CORBETTA, N., CHAMBERLAIN, P.F., RAI, V., SARGENT, I.L., REDMAN, C.W.G. and WAINSCOAT, J.S. (1997). Presence of fetal DNA in maternal plasma and serum. Lancet 350: 485-487.

LO, Y.M.D., LUN, F.M.F., CHAN, K.C.A., TSUI, N.B.Y., CHONG, K.C., LAU, T.K., LEUNG, T.Y., ZEE, B.C.Y., CANTOR, C.R. and CHIU, R.W.K. (2007). From the Cover: Digital PCR for the molecular detection of fetal chromosomal aneuploidy. Proc Nat/ Acad Sci USA 104: 13116-13121.

LO, Y.M.D., ZHANG, J., LEUNG, T.N., LAU, T.K., CHANG, A.M.Z. and HJELM, N.M. (1999). Rapid Clearance of Fetal DNA from Maternal Plasma. Am J Hum Genet 64: 218-224.

LOUBIERE, L.S., LAMBERT, N.C., FLINN, L.J., ERICKSON, T.D., YAN, Z., GUTHRIE, K.A., VICKERS, K.T. and NELSON, J.L. (2006). Maternal microchimerism in healthy adults in lymphocytes, monocyte//macrophages and NK cells. Lab Invest 86: 1185-1192.

MAHANTY, H.D., CHERIKH, W.S., CHANG, G.J., BAXTER-LOWE, L.A. and ROBERTS, J.P. (2001). Influence of pretransplant pregnancy on survival of renal allografts from living donors. Transplantation 72: 228-232.

MALONEY, S., SMITH, A., FURST, D.E., MYERSON, D., RUPERT, K., EVANS, P.C. and NELSON, J.L. (1999). Microchimerism of maternal origin persists into adult life. J Clin Invest 104: 41-47.

MAUREL, M.C. and KANELLOPOULOS-LANGEVIN, C. (2008). Heredity - Venturing Beyond Genetics. Biol Reprod79: 2-8.

MCGRATH, H. (2004). Elective pregnancy termination and microchimerism: Comment on the article by Khosrotehrani et al. Arthritis Rheum 50: 3058-3059.

MCNALLAN, K.T., APONTE, C., EL-AZHARY, R., MASON, T., NELSON, A.M., PAAT, J.J., CROWSON, C.S. and REED, A.M. (2007). Immunophenotyping of chimeric cells in localized scleroderma. Rheumatology 46: 398-402.

MIJARES-BOECKH-BEHRENS, T., SELVA-O'CALLAGHAN, A., SOLANS-LAQUE, R., BOSCH-GIL, J., VILARDELL-TARRES, M., BALADA-PRADES, E., KUWANA, M., OGAWA, Y. and TODA, I. (2001). Fetal microchimerism in Sjögren's syndrome. Ann Rheum Dis 60: 897-898.

MIKHAIL, M.A., M'HAMDI, H., WELSH, J., LEVICAR, N., MARLEY, S.B., NICHOLLS, J.P., HABIB, N.A., LOUIS, L.S., FISK, N.M. and GORDON, M.Y. (2008). High frequency of fetal cells within a primitive stem cell population in maternal blood. Hum Reprod 23: 928-933.

MIYASHITA, Y., ONO, M., ONO, M., UEKI, H. and KURASAWA, K. (2000). Y chromosome microchimerism in rheumatic autoimmune disease. Ann Rheum Dis 59: 655-656.

MOSCA, M., CURCIO, M., LAPI, S., VALENTINI, G., D'ANGELO, S., RIZZO, G. and BOMBARDIERI, S. (2003). Correlations of $Y$ chromosome microchimerism with disease activity in patients with SLE: analysis of preliminary data. Ann Rheum Dis 62: 651-654.

MURATA, H., NAKAUCHI, H. and SUMIDA, T. (1999). Microchimerism in Japanese women patients with systemic sclerosis. Lancet 354: 220-220.

NELSON, J.L. (1996). Maternal-fetal immunology and autoimmune disease: is some autoimmune disease auto-alloimmune or allo-autoimmune? Arthritis Rheum 39: 191-194.

NELSON, J.L. (1998a). Microchimerism and Autoimmune Disease. N Eng/J Med 338: 1223-1225.

NELSON, J.L. (1998b). Microchimerism and the pathogenesis of systemic sclerosis. Curr Opin Rheumato/ 10: 564-571.

NELSON, J.L., FURST, D.E., MALONEY, S., GOOLEY, T., EVANS, P.C., SMITH, A., BEAN, M.A., OBER, C. and BIANCHI, D.W. (1998). Microchimerism and HLA-compatible relationships of pregnancy in scleroderma. Lancet 351: 559562.

NELSON, J.L., GILLESPIE, K.M., LAMBERT, N.C., STEVENS, A.M., LOUBIERE, L.S., RUTLEDGE, J.C., LEISENRING, W.M., ERICKSON, T.D., YAN, Z.,
MULLARKEY, M.E., BOESPFLUG, N.D., BINGLEY, P.J. and GALE, E.A.M (2007). Maternal microchimerism in peripheral blood in type 1 diabetes and pancreatic islet beta cell microchimerism. Proc Natl Acad Sci USA 104: 16371642.

NELSON, J.L., HUGHES, K.A., SMITH, A.G., NISPEROS, B.B., BRANCHAUD, A.M. and HANSEN, J.A. (1993). Maternal-Fetal Disparity in HLA Class II Alloantigens and the Pregnancy-Induced Amelioration of Rheumatoid Arthritis. N Eng/J Med 329: 466-471.

O'DONOGHUE, K., CHAN, J., DELAFUENTE, J., KENNEA, N., SANDISON, A., ANDERSON, J.R., ROBERTS, I.A.G. and FISK, N.M. (2004). Microchimerism in female bone marrow and bone decades after fetal mesenchymal stem-cell trafficking in pregnancy. Lancet 364: 179-182.

OHTSUKA, T., MIYAMOTO, Y., YAMAKAGE, A. and YAMAZAKI, S. (2001). Quantitative analysis of microchimerism in systemic sclerosis skin tissue. Arch Dermatol Res 293: 387-391.

OSTENSEN, M.E. and NELSON, J.L. (2004). Pregnancy. Rheumatoid Arthritis. E. S. Clair, D. Pisetsky and B. Hayes. Philadelphia, PA, Lippincott Williams Wilkins: 496-503.

PANI, M.A., VANAUTREVE, J., VANDERAUWERA, B.J., GORUS, F.K. and BADENHOOP, K. (2002). Non-transmitted maternal HLA DQ2 or DQ8 alleles and risk of Type I diabetes in offspring: the importance of foetal or post partum exposure to diabetogenic molecules. Diabetologia 45: 1340-1343.

PEDERSEN, I.B., LAURBERG, P., KNUDSEN, N., JORGENSEN, T., PERRILD, H., OVESEN, L. and RASMUSSEN, L.B. (2006). Lack of association between thyroid autoantibodies and parity in a population study argues against microchimerism as a trigger of thyroid autoimmunity. Eur J Endocrino/154: 3945.

PIOTROWSKI, P. and CROY, B.A. (1996). Maternal cells are widely distributed in murine fetuses in utero. Biol Reprod 54: 1103-1110.

PITTMAN, K.M., LOSKEN, H.W., KLEINMAN, M.E., MARCUS, J.R., BLEI, F., GURTNER, G.C. and MARCHUK, D.A. (2006). No Evidence for Maternal-Fetal Microchimerism in Infantile Hemangioma: A Molecular Genetic Investigation. $J$ Invest Dermato/126: 2533-2538.

POLLACK, M.S., KIRPATRICK, D., KAPOOR, D., SUPOR, V. and OREILLY, R.J. (1982). Identification by HLA typing of intrauterine derived maternal T cells in four patients with severe combined immunodeficiency. NEng/J Med307: 662666.

PORTANOVA, J.P. and KOTZIN, B.L. (1988). Lupus-like autoimmunity in murine graft-versus-host disease. Concepts Immunopatho/6: 119-140.

REED, A.M., PICORNELL, Y.J., HARWOOD, A. and KREDISH, D.W. (2000). Chimerism in children with juvenile dermatomyositis. Lancet 356: 2156.

REGAUER, S., SCHWAIGER, P., LIEGL, B. and KLINTSCHAR, M. (2004). Fetal Microchimerism Is Common in Normal and Diseased Vulvar Skin. $J$ Invest Dermato/122: 1059-1060.

REGNIER, S., DUPIN, N., DANFF, C.L., WASSEF, M., ENJOLRAS, O. and ARACTINGI, S. (2007). Endothelial cells in infantile haemangiomas originate from the child and not from the mother (a fluorescence in situ hybridizationbased study). Br J Dermato/157: 158-160.

RENNE, C., RAMOS-LOPEZ, E., STEIMLE-GRAUER, S.A., ZIOLKOWSKI, P., PANI, M.A., LUTHER, C., HOLZER, K., ENCKE, A., WAHL, R.A., BECHSTEIN, W.O., USADEL, K.H., HANSMANN, M.L. and BADENHOOP, K. (2004). Thyroid Fetal Male Microchimerisms in Mothers with Thyroid Disorders: Presence of $Y$ Chromosomal Immunofluorescence in Thyroid-Infiltrating Lymphocytes Is More Prevalent in Hashimoto's Thyroiditis and Graves' Disease Than in Follicular Adenomas. J Clin Endocrinol Metab 89: 5810-5814.

REYNOLDS, A.G. (1955). Placental metastasis from malignant melanoma; report of a case. Obstet Gyneco/6: 205-209.

ROSSI, G. (2004). Nature of stem cell involved in fetomaternal microchimerism. Lancet 364: 1936.

SAWAYA, H.H.B., JIMENEZ, S.A. and ARTLETT, C.M. (2004). Quantification of fetal microchimeric cells in clinically affected and unaffected skin of patients with systemic sclerosis. Rheumatology 43: 965-968.

SCALETTI, C., VULTAGGIO, A., BONIFACIO, S., EMMI, L., TORRICELLI, F., MAGGI, E., ROMAGNANI, S. and PICCINNI, M.P. (2002). Th2-oriented profile of male offspring $T$ cells present in women with systemic sclerosis and reactive with maternal major histocompatibility complex antigens. Arthritis Rheum 46: $445-450$. 
SCHMORL, C.G. (1893). Pathologisch-anatomische Untersuchungen uber Puerperal-Eklampsie. Verlag FCW Vogel.

SCHÖNIGER-HEKELE, M., MÜLLER, C., ACKERMANN, J., DRACH, J., WRBA, F., PENNER, E. and FERENCI, P. (2002). Lack of Evidence for Involvement of Fetal Microchimerism in Pathogenesis of Primary Biliary Cirrhosis. Dig Dis SCi 47: 1909-1914.

SCHRODER, J. and DELACHAPELLE, A. (1972). Fetal Lymphocytes in the Maternal Blood. Blood 39: 153-162.

SCHRODER, J., THLIKAINEN, A. and DELACHAPELLE, A. (1974). Fetal leukocytes in the maternal circulation after delivery: Cytological aspects. Transplantation 17: 346-354.

SELVA-O'CALLAGHAN, A., BOECKH-BEHRENS, T.M., BALADA-PRADES, E., SOLANS-LAQUE, R. and VILARDELL-TARRÉS, M. (2001). Fetal microchimerism and inflammatory myopathies. Lancet 357: 887-887.

SELVA-O'CALLAGHAN, A., MIJARES-BOECKH-BEHRENS, T., PRADES, E.B., SOLANS-LAQUE, R., SIMEON-AZNAR, C.P., FONOLLOSA-PLA, V. and VILARDELL-TARRES, M. (2003). Lack of evidence of foetal microchimerism in female Spanish patients with systemic sclerosis. Lupus 12: 15-20.

SRIVATSA, B., SRIVATSA, S., JOHNSON, K.L. and BIANCHI, D.W. (2003). Maternal cell microchimerism in newborn tissues. J Pediatr 142: 31-35.

SRIVATSA, B., SRIVATSA, S., JOHNSON, K.L., SAMURA, O., LEE, S.L. and BIANCHI, D.W. (2001). Microchimerism of presumed fetal origin in thyroid specimens from women: a case-control study. Lancet 358: 2034-2038.

STERN, M., RUGGERI, L., MANCUSI, A., BERNARDO, M.E., DEANGELIS, C., BUCHER, C., LOCATELLI, F., AVERSA, F. and VELARDI, A. (2008). Survival after T-cell depleted haploidentical stem cell transplantation is improved using the mother as donor. Blood. blood-2008-01-135285.

STEVENS, A.M., HERMES, H.M., LAMBERT, N.C., NELSON, J.L., MERONI, P.L. and CIMAZ, R. (2005). Maternal and sibling microchimerism in twins and triplets discordant for neonatal lupus syndrome-congenital heart block. Rheumatology 44: 187-191.

STEVENS, A.M., HERMES, H.M., RUTLEDGE, J.C., BUYON, J.P. and NELSON, J.L. (2003). Myocardial-tissue-specific phenotype of maternal microchimerism in neonatal lupus congenital heart block. Lancet 362: 1617-1623.

STEVENS, A.M., MCDONNELL, W.M., MULLARKEY, M.E., PANG, J.M., LEISENRING, W. and NELSON, J.L. (2004). Liver biopsies from human females contain male hepatocytes in the absence of transplantation. Lab Invest 84: 1603-1609.

STEVENS, A.M., TSAO, B.P., HAHN, B.H., GUTHRIE, K., LAMBERT, N.C., PORTER, A.J., TYLEE, T.S. and NELSON, J.L. (2005). Maternal HLA class II compatibility in men with systemic lupus erythematosus. Arthritis Rheum 52: 2768-2773.

SU, E.C., JOHNSON, K.L., TIGHIOUART, H. and BIANCHI, D.W. (2008). Murine Maternal Cell Microchimerism: Analysis Using Real-Time PCR and In vivo Imaging. Biol Reprod78: 883-887.

SURBEK, D.V., GRATWOHL, A. and HOLZGREVE, W. (1999). In utero hematopoietic stem cell transfer: current status and future strategies. EurJ Obstet Gynecol Reprod Bio/85: 109-115.

SUSKIND, D.L., ROSENTHAL, P., HEYMAN, M.B., KONG, D., MAGRANE, G., BAXTER-LOWE, L.A. and MUENCH, M.O. (2004). Maternal microchimerism in the livers of patients with biliary atresia. BMC Gastroentero/4.

SWINKELS, D.W., DEKOK, J.B., HENDRIKS, J.C.M., WIEGERINCK, E., ZUSTERZEEL, P.L.M. and STEEGERS, E.A.P. (2002). Hemolysis, elevated liver enzymes, and low platelet count (HELLP) syndrome as a complication of preeclampsia in pregnant women increases the amount of cell-free fetal and maternal DNA in maternal plasma and serum. Clin Chem 48: 650-653.

TAN, X.W., LIAO, H., SUN, L., OKABE, M., XIAO, Z.C. and DAWE, G.S. (2005). Fetal Microchimerism in the Maternal Mouse Brain: A Novel Population of Fetal Progenitor or Stem Cells Able to Cross the Blood-Brain Barrier? Stem Cells 23: 1443-1452.

TANAKA, A., LINDOR, K., GISH, R., BATTS, K., SHIRATORI, Y., OMATA, M., NELSON, J.L., ANSARI, A., COPPEL, R., NEWSOME, M. and GERSHWIN, M.E. (1999). Fetal microchimerism alone does not contribute to the induction of primary biliary cirrhosis. Hepatology 30: 833-838.
TANEI, R., YOKONO, H., MOTOORI, T. and KATSUOKA, K. (2000). Microchimerism seems uninvolved in the pathogenesis of idiopathic lichen planus. Dermatology 201: 373-374.

TENWOLDE, S., BREEDVELD, F.C., DEVRIES, R.R., DAMARO, J., RUBENSTEIN, P. and SCHREUDER, G.M. (1993). Influence of non-inherited maternal HLA antigens on occurrence of rheumatoid arthritis. Lancet 341: 200-202.

THOMAS, M.R., WILLIAMSON, R., CRAFT, I., YAZDANI, N. and RODECK, C.H. (1994). Y chromosome sequence DNA amplified from peripheral blood of women in early pregnancy. Lancet343: 413-414.

TODA, I., KUWANA, M., TSUBOTA, K. and KAWAKAMI, Y. (2001). Lack of evidence for an increased microchimerism in the circulation of patients with Sjogren's syndrome. Ann Rheum Dis 60: 248-253.

TOKITA, K., TERASAKI, P., MARUYA, E. and SAJI, H. (2001). Tumour regression following stem cell infusion from daughter to microchimeric mother. Lancet 358 : 2047-2048.

TYNDALL, A. and GRATWOHL, A. (1998). Microchimerism: Friend or foe? Nat Med 4: 386-388.

VABRES, P., MALINGE, M.C., LARRÈGUE, M. and BONNEAU, D. (2002). Microchimerism from a dizygotic twin in juvenile ulcerative lichen planus. Lancet 359: 1861-1862.

VAN WIJK, I.J., DE HOON, A.C., JURHAWAN, R., TJOA, M.L., GRIFFIOEN, S., MULDERS, M.A.M., VAN VUGT, J.M.G. and OUDEJANS, C.B.M. (2000). Detection of Apoptotic Fetal Cells in Plasma of Pregnant Women. Clin Chem 46: 729-731.

VERDIJK, R.M., KLOOSTERMAN, A., POOL, J., VANDEKEUR, M., NAIPAL, A.M.I.H., VANHALTEREN, A.G.S., BRAND, A., MUTIS, T. and GOULMY, E. (2004). Pregnancy induces minor histocompatibility antigen-specific cytotoxic $T$ cells: implications for stem cell transplantation and immunotherapy. Blood103: 1961-1964.

WALKNOWSKA, J., CONTE, F.A. and GRUMBACH, M.M. (1969). Practical and theoretical implications of fetal/maternal lymphocyte transfer. Lancet 7606 : 1119-1122.

WALSH, J.P., BREMNER, A.P., BULSARA, M.K., O'LEARY, P., LEEDMAN, P.J., FEDDEMA, P. and MICHELANGELI, V. (2005). Parity and the Risk of Autoimmune Thyroid Disease: A Community-Based Study. J Clin Endocrino/Metab90: 5309-5312.

WANG, Y., IWATANI, H., ITO, T., HORIMOTO, N., YAMATO, M., MATSUI, I., IMAI, E. and HORI, M. (2004). Fetal cells in mother rats contribute to the remodeling of liver and kidney after injury. Biochem Biophys Res Commun 325: 961-967.

WEGER, W., BAUER, M., ODELL, E., PERTL, B., CERRONI, L., KERL, H., JAKSE, $\mathrm{N}$. and PERTL, C. (2006). Role of microchimerism in the pathogenesis of oral lichen planus. Exp Dermato/15: 125-129.

WILLER, C.J., HERRERA, B.M., MORRISON, K.M.E., SADOVNICK, A.D. and EBERS, G.C. (2006). Association between microchimerism and multiple sclerosis in Canadian twins. J Neuroimmuno/179: 145-151.

WILLIAMS (1907). Obstetrics: A textbook for the use of students and practitioners. New York, Appleton Press.

WRENSHALL, L.E., STEVENS, E.T., SMITH, D.R. and MILLER, J.D. (2007). Maternal microchimerism leads to the presence of interleukin-2 in interleukin2 knock out mice: Implications for the role of interleukin-2 in thymic function. Cell Immuno/245: 80-90.

YAN, Z., LAMBERT, N.C., GUTHRIE, K.A., PORTER, A.J., LOUBIERE, L.S., MADELEINE, M.M., STEVENS, A.M., HERMES, H.M. and NELSON, J.L. (2005). Male microchimerism in women without sons: Quantitative assessment and correlation with pregnancy history. Am J Med 118: 899-906.

YAN, Z., LAMBERT, N.C., ØSTENSEN, M., ADAMS, K.M., GUTHRIE, K.A. and NELSON, J.L. (2006). Prospective study of fetal DNA in serum and disease activity during pregnancy in women with inflammatory arthritis. Arthritis Rheum 54: 2069-2073.

ZHONG, X.Y., LAIVUORI, H., LIVINGSTON, J.C., YLIKORKALA, O., SIBAI, B.M. HOLZGREVE, W. and HAHN, S. (2001). Elevation of both maternal and fetal extracellular circulating deoxyribonucleic acid concentrations in the plasma of pregnant women with preeclampsia. Am J Obstet Gyneco/184: 414-419. 


\section{Further Related Reading, published previously in the Int. J. Dev. Biol.}

See our recent Special Issue Epigenetics \& Development edited by Saadi Khochbin and Stefan Nonchev at: http://www.ijdb.ehu.es/web/contents.php?vol=53\&issue=2-3

See Special Issue Pattern Formation edited by Michael K. Richardson and Cheng-Ming Chuong at: http://www.ijdb.ehu.es/web/contents.php?vol=53\&issue =5-6

Receptor-mediated uptake and transport of macromolecules in the human placenta Henning Schneider and Richard K. Miller Int. J. Dev. Biol. (2010) 54: 367-375 (doi: 10.1387/ijdb.082773hs)

Local regulation of implantation at the human fetal-maternal interface Evdokia Dimitriadis, Guiying Nie, Natalie J. Hannan, Premila Paiva and Lois A. Salamonsen Int. J. Dev. Biol. (2010) 54: 313-322 (doi: 10.1387/ijdb.082772ed)

Prolonged human/sheep cellular chimerism following transplantation of human hemopoietic stem cells into the ewe celomic cavity

Monica Michelini, Sandra Papini, Alfredo Rosellini, Giuseppe Noia, Maria S. Ligato, Salvatore Mancuso, Andrea Cavazzana, Gloria Bertacca, Claudio Di Cristofano, Riccardo Saccardi, Serena Urbani and Roberto P. Revoltella Int. J. Dev. Biol. (2008) 52: 365-370

Puzzles of mammalian fertilization - and beyond J. Michael Bedford Int. J. Dev. Biol. (2008) 52: 415-426

An activating mutation in the PDGF receptor-beta causes abnormal morphology in the mouse placenta

Camilla Looman, Tong Sun, Yang Yu, Agata Zieba, Aive Ahgren, Ricardo Feinstein, Henrik Forsberg, Carina Hellberg, Carl-Henrik Heldin, Xiao-Qun Zhang, Karin Forsberg-Nilsson, Nelson Khoo, Reinald Fundele and Rainer Heuchel Int. J. Dev. Biol. (2007) 51: 361-370

A simple in vivo approach to investigate invasive trophoblast cells Juan A. Arroyo, Toshihiro Konno, Darya C. Khalili and Michael J. Soares Int. J. Dev. Biol. (2005) 49: 977-980

Control of reproduction by Polycomb Group complexes in animals and plants Anne-Elisabeth Guitton and Frederic Berger

Int. J. Dev. Biol. (2005) 49: 707-716

Commitment of hematopoietic stem cells in avian and mammalian embryos: an ongoing story

Françoise Dieterlen-Lièvre

Int. J. Dev. Biol. (2005) 49: 125-130

Dynamic readjustment of parental methylation patterns of the 5'-flank of the mouse $\mathrm{H} 19$ gene during in vitro organogenesis.

L Liang, C Kanduri, M Pilartz, K Svensson, J H Song, P Wentzel, U Eriksson and R Ohlsson Int. J. Dev. Biol. (2000) 44: 785-790

Met signaling mutants as tools for developmental studies.

C Ponzetto, G Panté, C Prunotto', A leraci and F Maina

Int. J. Dev. Biol. (2000) 44: 645-653

Incorporation of cultured embryonic cells into transgenic and chimeric, porcine fetuses. E Notarianni, S Laurie, A NG and K Sathasivam

Int. J. Dev. Biol. (1997) 41: 537-540

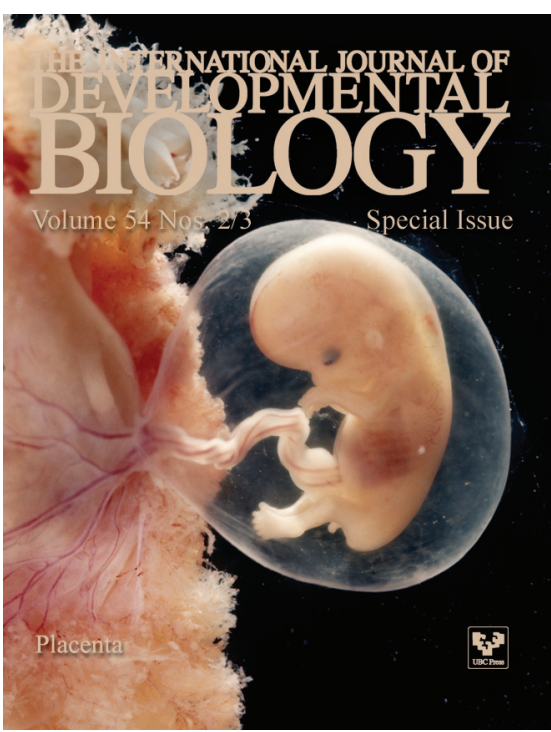

5 yr ISI Impact Factor $(2008)=3.271$

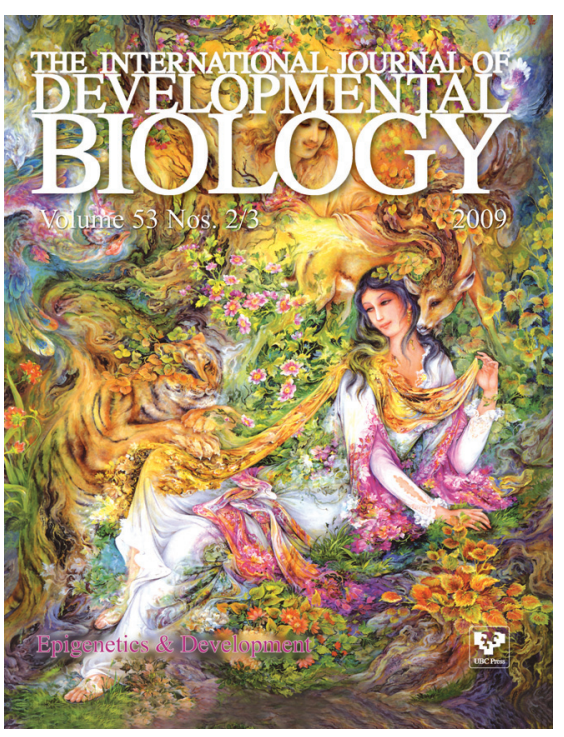

